\title{
Synthesis, Structure and Reactivity of Sulfur-Rich Cyclopentadienyl-Transition Metal Complexes: Sulfur Chemistry from an Organometallic Point of View
}

\author{
By Joachim Wachter *
}

Metal-sulfur centers play an important role in the activity of metalloproteins in enzymatic catalysis and the activity of metal sulfides as heterogeneous catalysts. The systematic search for M-S model compounds led to the discovery of an interesting and novel structural chemistry, which stems from the numerous coordination possibilities of sulfur ligands. The intention of this review article is to present and outline new approaches to sulfur chemistry from the organometallic point of view. Reactive cyclopentadienyl-transition metal fragments incorporate elemental sulfur to give polynuclear sulfur-rich complexes, which can contain either mono-, di- or polysulfido ligands or several such ligands in combined form. The versatile structural chemistry of the complexes formed and their reactivity towards organic, inorganic and organometallic compounds are discussed, and examples of some simple and rational procedures for their synthesis starting from cyclopentadienylcarbonyl- and cyclopentadienylhydrido-complexes are outlined. Their reactivity is manifested in numerous metal-and ligandcentered reactions. Finally the, albeit far less extensive, complex chemistry of the other chalcogens $(\mathrm{O}, \mathrm{Se}, \mathrm{Te})$ is also considered for comparison, thus providing a more detailed survey of particular aspects of this area of chemistry.

\section{Introduction}

The chemistry of soluble transition metal sulfides is virtually inexhaustible. Whether one is considering the stabilization of unusual bonding systems or molecular model compounds, the immense range of possibilities available to sulfur in metal complex ligands is impressive.

Metal-sulfur complexes are, for example, of special interest with regard to the modes of action and the structures of many enzymes. The as yet unsolved problem of the structure of the active center of nitrogenase - the enzyme system that converts atmospheric nitrogen into ammonia-is often cited as example to demonstrate just how difficult it is to obtain structural information of biological centers indirectly using even the best possible model complexes. ${ }^{[1]}$

Metal sulfides also play a role in the desulfurization of fossil fuels by hydrogenation (e.g. hydrodesulfurization, HDS). ${ }^{[2]}$ Utilization of the worlds sulfur-containing resources in an economic and environmentally unobjectionable way demands that basic research be carried out on soluble model systems--the HDS process actually occurs on a heterogeneous metall sulfide surface.

It is obvious from the examples already quoted that simple model systems in the form of soluble transition metal sulfides are required in order to extend our existing knowledge of sulfur coordination chemistry. The effort being made in this direction is reflected in the number of reviews of complexes with mono- ${ }^{[3]}$ di- ${ }^{[4]}$ and polysulfido ligands. ${ }^{\left[{ }^{[f]}\right.}$ Parallel to these investigations a new research area has been opened up with the chemistry of polynuclear sulfur-rich transition metal complexes. The addition of elemental sulfur to reactive cyclopentadienylmetal fragments and subsequent fragmen-

[*] Dr. J. Wachter,

Institut für Anorganische Chemie der Universität

Universitätsstrasse 31 ,

D-8400 Regensburg (FRG) tation of the generally unisolable primary products leads predominantly to binuclear complexes. The advantages offered by this chemistry are the generally uncomplicated synthetic strategies, the good solubility of the products, and the readiness of the products to undergo further reactions. The use of cyclopentadienyl carbonyl complexes often enables the spectroscopic observation and isolation of intermediates that can provide valuable information about the degradation of the $S_{8}$ ring.

As already demonstrated in an earlier review of the structures of binuclear sulfur-rich cyclopentadienyl complexes, ${ }^{[6]}$ the sulfur: metal ratio varies from $1: 2$ to $10: 2$. The structure
A

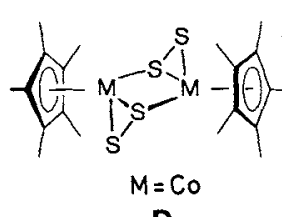

D

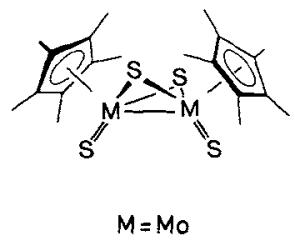

G

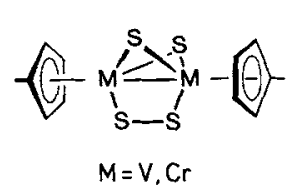

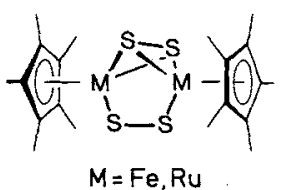

$B$

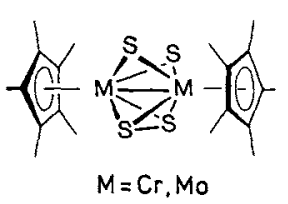

E

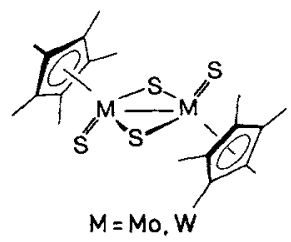

H

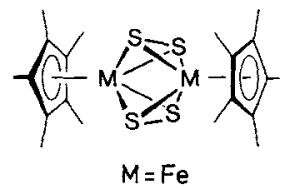

$\mathrm{C}$

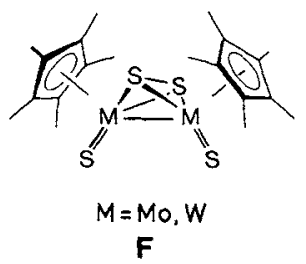

$F$
Scheme 1. Examples of possible structure types $(A-H)$ for $\left[C p_{2}^{(*)} M_{2} S_{4}\right]$ complexes. 
of the relatively simple molecules $\left[\mathrm{Cp}_{2}^{(*)} \mathrm{M}_{2} \mathrm{~S}_{4}\right]^{[*]}$ has alone been formulated in eight different ways to date (Scheme 1). This immediately calls for a clarification and comparison of the background information concerning the formation, structure and reactivity of all these complexes in relation to the nature of the central metal and to the influence of the substituents in the $\mathrm{Cp}^{(*)}$ ligand.

The number of analogous Se- and Te-complexes is still relatively small, but nevertheless the existing results allow a comparison to be made between the differing reactivities of the chalcogens and a given CpM fragment. Oxygen is an exception since there already exists an extensive V-complex and Re-complex chemistry. ${ }^{[7]}$ Even so, a discussion of the structural peculiarities of its complexes in comparison to the complexes of its higher homologues would appear stimulating.

\section{Syntheses and Structures}

\subsection{Cyclopentadienyl Sulfides and Selenides of the Electron-Deficient Transition Metals}

Rings with an even number of members in which two $\mathrm{Cp}_{2}^{(*)} \mathrm{M}$ fragments are present but do not directly interact with each other, are characteristic of the complexes 1 of the group 4 metals. There are many diverse methods available for the synthesis of such complexes. Ti-complexes 1 , for ex-

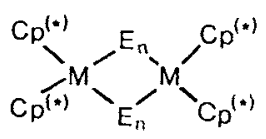

$1, M=\mathrm{Ti}, \mathrm{Zr}$

$E=S, n=1-3 ; E=S e, n=1,2$

ample, are accessible by desulfurization of $\mathrm{Cp}_{2}^{(*)} \mathrm{TiS}_{5}$ with $\mathrm{PR}_{3}$ (the number $\mathrm{n}$ of bridging chalcogen atoms in the product depends on the nucleophilicity of the phosphane ${ }^{[8]}$ ) or by the reaction of $\mathrm{Cp}_{2}^{\prime} \mathrm{TiCl}_{2}$ with $\mathrm{Li}_{2} \mathrm{Se}_{2}(\mathrm{n}=2) \cdot{ }^{[9]}$ Reaction of carbonyl derivatives such as $\mathrm{Cp}_{2}^{(*)} \mathrm{Ti}(\mathrm{CO})_{2}$ with $\mathrm{H}_{2} \mathrm{~S}^{[10]}$ or

[*] If not otherwise indicated the following abbreviations for the cyclopentadienyl ligands apply: $\mathrm{Cp}=\mathrm{C}_{5} \mathrm{H}_{5}, \mathrm{Cp}^{\prime}=\mathrm{MeC}_{5} \mathrm{H}_{4}, \mathrm{Cp}^{*}=\mathrm{C}_{5} \mathrm{Me}_{5}, \mathrm{Cp}^{(*)}=$ any other substituted cyclopentadienyl ring. These ligands are $\eta^{5}$-coordinated in all cases.
$\mathrm{H}_{2} \mathrm{Se}^{[11]}$ yields the kinetically labile complexes $1(\mathrm{n}=1)$. These form symmetrical clusters at higher temperatures, e.g. $\left[\mathrm{Cp}_{4} \mathrm{Ti}_{4} \mathrm{Se}_{4}\right]$. A less pungent and less toxic way to complexes of type 1 is via the reaction of $\mathrm{Cp}_{2}^{\prime} \mathrm{Zr}$, prepared in situ, with elemental $S$ or Se. ${ }^{[12]}$ Two different sorts of chalcogen bridges can be found in $\left[\mathrm{Cp}_{4} \mathrm{Hf}_{2}(\mu-\mathrm{O})\left(\mu-\mathrm{Se}_{4}\right)\right],{ }^{[13]}$ the only known binuclear hafnium compound. It is formed from $\mathrm{Cp}_{2} \mathrm{HfSe}_{5}$ by exposure to air.

The sulfur-rich vanadium complexes $\left[\mathrm{Cp}_{2}^{(*)} \mathrm{V}_{2} \mathrm{E}_{\mathrm{n}}\right] \mathbf{2 - 4}$ $(E=S, S e ; n=3-5)$ are structurally completely different from the binuclear complexes 1 . The diamagnetic compounds 2 can be prepared either by thermolysis of $\mathrm{Cp}_{2}^{\prime} \mathrm{VE}_{5}{ }^{[14,15]}$ or by dehalogenation of $\mathrm{Cp}_{2} \mathrm{VCl}_{2}$ with $\mathrm{Se}\left(\mathrm{SiMe}_{3}\right)_{2}{ }^{[16]}$. Since these reactions occur with the elimination of a $\mathrm{Cp}^{(*)}$ ligand from each metal atom, the products strive to overcome their electron deficiency by utilizing three different chalcogen bridges as well as a metal-metal interaction $\left(d_{v-v} 2.66-2.77 \AA\right)$. An interesting and recurring phenomenon in complexes of the general composition $\left[\mathrm{Cp}_{2}^{(*)} \mathrm{M}_{2} \mathrm{~S}_{\mathrm{n}}\right](\mathrm{n} \geq 4)$ is the stabilization of unusual electron configurations at the metal by $M-E d_{n}-p_{\pi}$ interactions. ${ }^{[*]}$ Such stabilizations may be the driving force for the unusual sulfur abstraction from $2 \mathrm{a}\left(\mathrm{Cp}^{(*)}=\mathrm{Cp}^{\prime}\right)$ by $\mathrm{PBu}_{3}$ with formation of the $26 \mathrm{e}$ complexes $3^{[18]}$ and $4 .^{[17]}$ Due to the very

$$
\begin{aligned}
& \mathrm{Cp}_{2}^{\prime} V E_{5} \stackrel{110^{\circ} \mathrm{C}}{\longrightarrow} \mathrm{C}(\mathrm{a}) \mathrm{Se}(\mathrm{b}) \mathrm{C} \\
& 2 a\left(c_{p}^{(m)}=C_{p}\right) \mid \mathrm{PBu}_{3}
\end{aligned}
$$

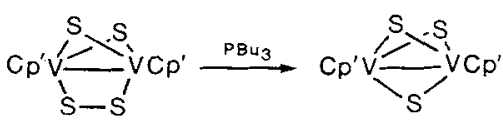

$$
\begin{aligned}
& 3 \\
& 4
\end{aligned}
$$

short $\mathrm{V}-\mathrm{S}$ distances $\left(\bar{d}_{\mathrm{v}-\mathrm{s}} 2.23 \AA\right)$ for all sulfur atoms, an alternative view of the general system of 3 and 4 with 34 valence electrons was suggested..$^{[18]}$

[*] With a neutral charge distribution the contribution of the chalcogen ligands to the electron count of 2 is $2(\mu-E)+2\left(\mu, \eta^{1}-E_{2}\right)+6\left(\mu, \eta^{2}-E_{2}\right)$ electrons, which together with the $2 \times 10$ electrons from the two $C \mathrm{p}^{(*)} \mathrm{V}$ units adds up to $30 \mathrm{e}[3,4]$. The alternative view with $\mu-\mathrm{E}^{2 \theta}, \mu, \eta^{1}-\mathrm{E}_{2}^{2 \theta}$, and $\mu, \eta^{2}-\mathrm{E}_{2}^{2-}$ ligands $(4+4+8)$ and two $V^{4 \oplus}$ centers leads to a similar result.

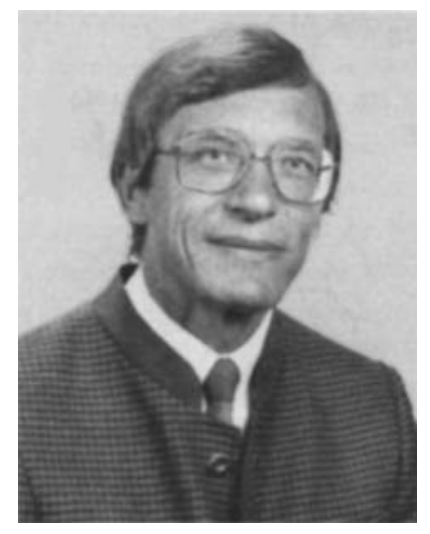

Joachim Wachter was born in 1945 in Böhmen and spent his early years in Riedenburg (Bavaria). He studied chemistry up to Diploma level at the University of Munich and received his doctorate from the University of Regensburg under Prof. Dr. H. Brunner. 1978/79 he carried out postdoctoral research with Prof. J. G. Riess in Nizza. Since 1977 he has been "Akademischer Oberrat" at the University of Regensburg. His research interests lie in the field of organometallic-chalcogen complexes and metal-metal multiple bonds. 
The examples of sulfur-rich $\mathrm{CpNb}$ dimers known to date apparently show more similarities to Ti-complexes than to V-complexes. Thus, in principle, $\left[\mathrm{Cp}_{4} \mathrm{Nb}_{2} \mathrm{~S}_{2}\right]^{[19]}$ belongs to the same structure type as 1 , despite its weak $\mathrm{Nb}-\mathrm{Nb}$ interaction $\left(d_{\mathrm{Nb}-\mathrm{Nb}} 3.23 \AA\right)$. A mixture of most likely very similar polysulfido complexes is formed upon reaction of $\left(t \mathrm{BuC}_{5} \mathrm{H}_{4}\right)_{2} \mathrm{NbH}_{3}$ with $\mathrm{S}_{8}$. The structure of 5 , in which the

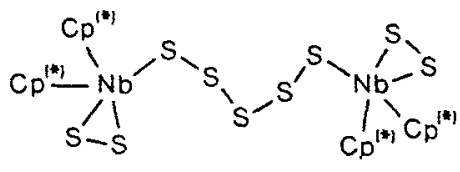

5

two $\left(t \mathrm{BuC}_{5} \mathrm{H}_{4}\right)_{2} \mathrm{Nb}\left(\eta^{2}-\mathrm{S}_{2}\right)$ units are connected by an $\mathrm{S}_{5}$ chain, was determined by an $\mathrm{X}$-ray crystallographic analysis. ${ }^{[20]}$ The above-mentioned mixture of polysulfido complexes can, depending on the large number of $\mathrm{S}-\mathrm{S}$ bonds, be converted in toluene at $100^{\circ} \mathrm{C}$ into three trinuclear clusters of slightly less sulfur content, of which 6 and 7 have been fully characterized (Fig. 1). The niobium-sulfur skeleton of 6
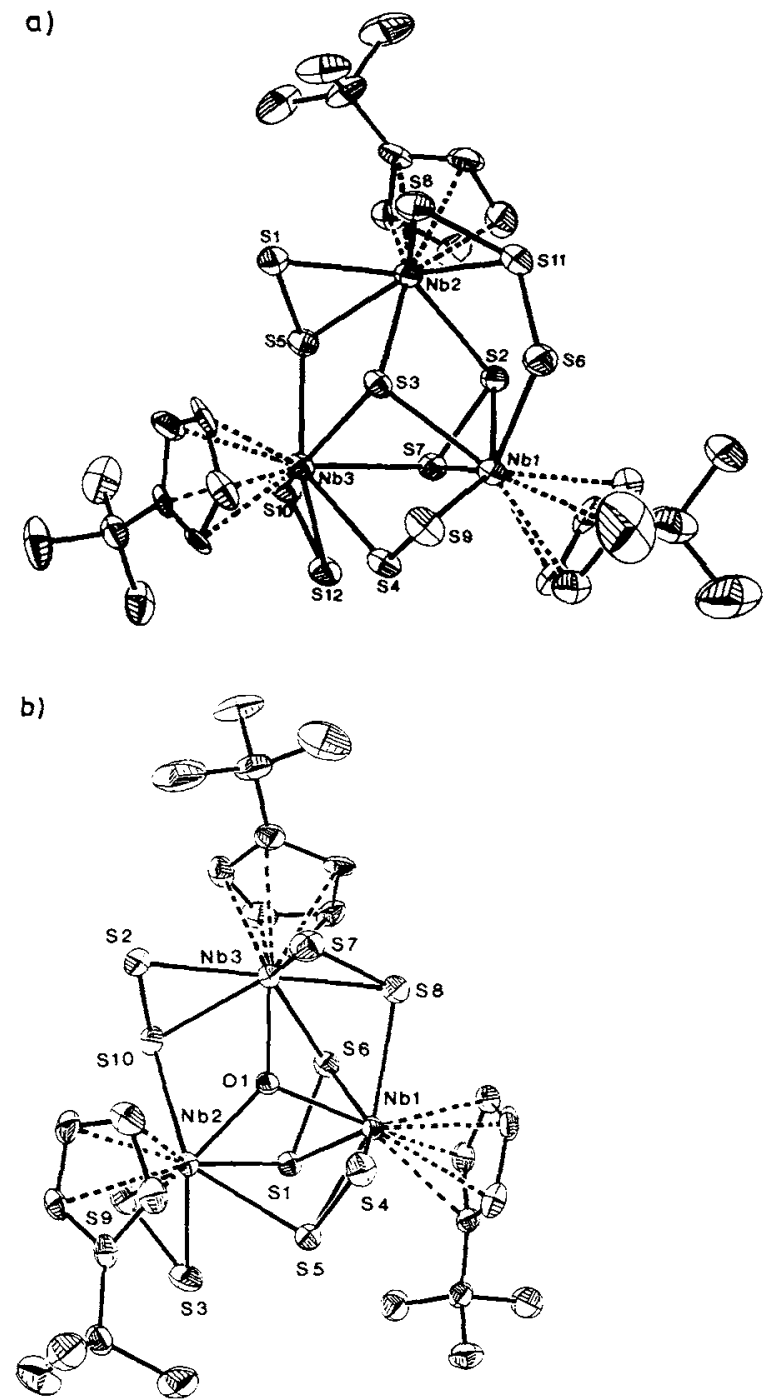

Fig. 1. a) Structure of $\left[\left(t \mathrm{BuC}_{5} \mathrm{H}_{4}\right)_{3} \mathrm{Nb}_{3} \mathrm{~S}_{12}\right] 6$ in the crystal. The $\mathrm{S}_{2}$ ligand S4-S9 is bound $\eta^{2}$ to $\mathrm{Nbl}$. b) Structure of $\left[\left(t \mathrm{BuC} \mathrm{C}_{5} \mathrm{H}_{4}\right)_{3} \mathrm{Nb}_{3} \mathrm{~S}_{10} \mathrm{O}\right] 7$ in the crystal. shows not less than five different ligand types (Scheme 2) ${ }^{[20]}$ The core of the molecule (Fig. $1 \mathrm{a}$ ) is a much flattened $\mathrm{Nb}_{3} \mathrm{~S}$ tetrahedron, whose base is spanned by a triply bridging $S_{2}$ group. Two $\mathrm{Nb}-\mathrm{Nb}$ bonds are each bridged by an $\eta^{1}, \eta^{2}-\mathrm{S}_{2}$ ligand. In contrast, $\mathrm{Nb1}-\mathrm{Nb} 2$ is bridged by an $\eta^{1}, \eta^{2}-\mathrm{S}_{3}$ ligand. The coordination sphere of $\mathrm{Nb} 3$ is completed by a terminal $\eta^{2}-S_{2}$ ligand.<smiles>[M][SH]([M])N</smiles>

$$
\mu_{3}-S
$$<smiles>[Si]1[Si]S1</smiles>

$$
n^{2}-s_{2}
$$<smiles>[M]C1[M][Si]1</smiles>
$\mu_{2} \cdot \eta^{1} \cdot \eta^{2}-s_{2}$ $4 e$<smiles>[M][M]1SC1[M]</smiles>
$\mu_{3} \cdot \eta^{1} \cdot \eta^{1} \cdot \eta^{2}-S_{2} \quad 6 e$<smiles>[M]S[S-]1=[S+][SH]1</smiles>

$\mu_{2} \cdot \eta^{9} \cdot \eta^{2}-S_{2}, 5$ $4 \mathrm{e}$

Scheme 2. Overview of representative sulfur ligand types found in $\mathbf{6}$, thei bonding, and the number of electrons which they-assumed as neutral-contribute to the bonding.

The structure of 7 (Fig. 1 b), which can also be prepared directly from 6 by heating for a longer time in toluene solution, is closely related to that of 6 . At the apex of the central tetrahedron there is an oxygen atom, however, and instead of the $S_{3}$ ligand there is now only an $\eta^{1}, \eta^{2}-S_{2}$ ligand. This has no electronic consequences, but as a first principle of order a uniform orientation of the points of the edge-bridging $\mathrm{S}_{2}$ ligands towards the top of the tetrahedron can be seen. This means that the compounds 6 and 7 differ in a remarkable way from the sulfur-bridged, but still halogen-containing clusters formed on reaction of $\mathrm{CpMHal}_{4}(\mathrm{M}=\mathrm{Nb}, \mathrm{Ta})$ with $\mathrm{S}\left(\mathrm{SiMe}_{3}\right)_{2},{ }^{[16]}$

The sulfurization of $\mathrm{Cp}$-carbonyl- $\mathrm{Nb}$ derivatives has until now only been investigated sporadically, although this entry to sulfur-rich cyclopentadienyl complexes has proven very successful for the later transition metal elements. Thus, reaction of $\left[\mathrm{CpNb}(\mathrm{CO})_{3}(\mathrm{thf})\right]$ with $\mathrm{S}_{8}$ leads to the $\mathrm{CO}$-free complex of the composition $\left[\mathrm{Cp}_{2} \mathrm{Nb}_{2} \mathrm{~S}_{5}\right]$. Its structure, however, is still unclear. ${ }^{[21]}$ It therefore remains to be seen whether the complexes $\left[\left\{\mathrm{CpNb}(\mathrm{CO})_{2}\right\}_{2}(\mu-\mathrm{S})_{n}\right](\mathrm{n}=2,3)$ are formed as intermediates en route to complexes with less $\mathrm{CO}$ - but a higher sulfur-content upon reaction of $\mathrm{H}_{2} \mathrm{~S}$ or $\mathrm{MeSH}$ and $[\mathrm{CpNb}-$ $(\mathrm{CO})_{3}($ thf $\left.)\right] .[21]$

\subsection{Binuclear Cyclopentadienyl Chalcogenides of the Chromium Triad}

\subsubsection{Complexes of the Type $/ \mathrm{Cp}_{2}^{(*)} \mathrm{Cr}_{2} \mathrm{~S}_{n} /(n=4,5)$}

Due to the reactivity of their $\mathrm{M}-\mathrm{M}$ triple bonds the complexes $\left[\mathrm{Cp}{ }^{(*)} \mathrm{M}(\mathrm{CO})_{2}\right]_{2}$ are generally the most suitable start- 
ing materials for the synthesis of sulfur-rich binuclear complexes of the $\mathrm{Cr}$ triad. Thus for example, reaction of $\left[\mathrm{Cp} * \mathrm{Cr}(\mathrm{CO})_{2}\right]_{2}$ and $\mathrm{S}_{8}$ affords the complex $8,{ }^{[22]}$ which in turn reacts with $\mathrm{PPh}_{3}$ with elimination of sulfur to give 9. [23] The complexes 8 and 9 are isoelectronic (each possessing 32

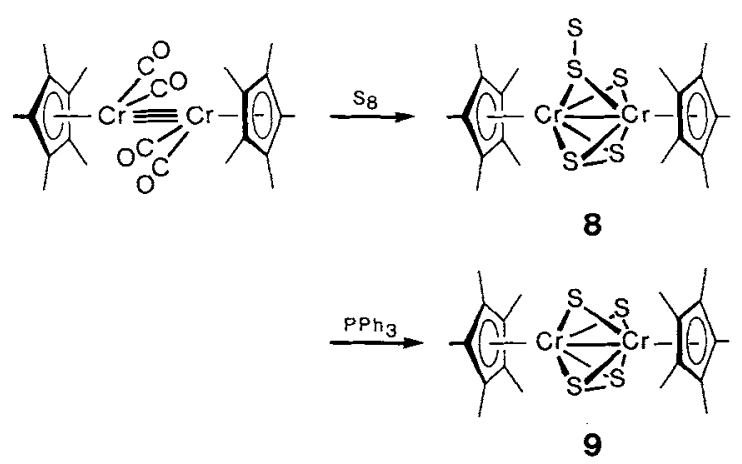

valence electrons) and therefore have similar structural frameworks resembling those of triple-decker compounds ${ }^{[22,24]}$ in which all bridging ligands lie in a plane perpendicular to the $\mathrm{Cr}-\mathrm{Cr}$ vector and parallel to the $\mathrm{Cp}^{*}$ rings. It is worth pointing out that 8 contains an $\eta^{1}-S, S$ bridge, in which only one $\mathrm{S}$ atom is coordinated to both $\mathrm{Cr}$ atoms (Fig. 2). The bent character of this moiety (S5 is orien-

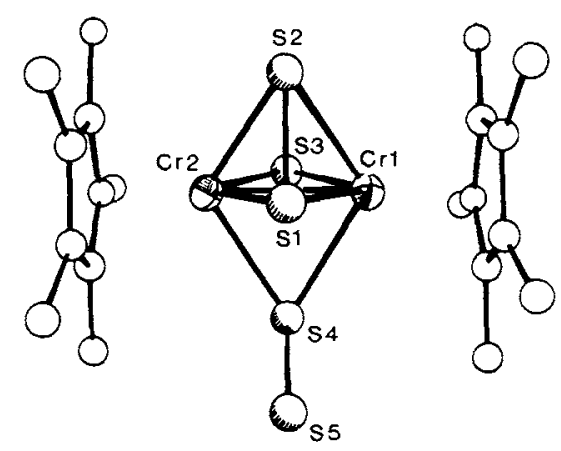

Fig. 2. Structure of 8 in the crystal.

tated towards the $\eta^{2}-S_{2}$ ligand) suggests a $2 \mathrm{e}$ donor (Scheme $3, \boldsymbol{J}$ and $\mathbf{K}$ ) and therefore not the valence tautomer $\mathbf{I}$, in which the $\eta^{1}-S_{2}$ ligand would effectively be a 4 e donor. In contrast its SO homologue $\left[\left\{\mathrm{Cp}(\mathrm{CO})_{2} \mathrm{Mn}\right\}_{2}(\mu-\mathrm{SO})\right]$ has the structure corresponding to $I^{[25]} \mathrm{A}$ participation of the reso-

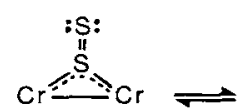

I
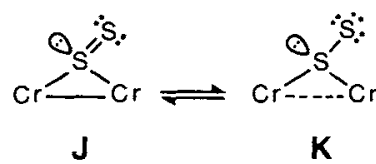

K
Scheme 3. Possible valence tautomerism of the $\mu, \eta^{1}-S, S$ ligand of 8 .

nance structure $\mathbf{K}$ explains the relatively long $\mathbf{S}-\mathbf{S}$ bond $(2.101 \AA)$ and the higher nucleophilicity of the terminal sulfur atom. ${ }^{[23,24]}$ The formation of the $\eta^{1}-S_{2}$ ligand is surprising, since it does not differ electronically from a $\mu-S$ ligand.

The reaction of $\left[\mathrm{CpCr}(\mathrm{CO})_{3}\right]_{2}$ with $\mathrm{S}_{8}$ is of a completely different character, since a relatively labile $\mathrm{Cr}-\mathrm{Cr}$ single bond makes the insertion of sulfur possible. Other than in the case of dimers of the iron triad (see, for example, 36 and 41 in Section 2.4) with a $\mathrm{Cr}$ dimer maximally $\mathrm{S}_{2}$ units are inserted into the $\mathrm{M}-\mathrm{M}$ bond and only two $\mathrm{CO}$ ligands are substituted. ${ }^{[26]}$ The main product 10 contains an almost linear CrSCr multiply bonded system. ${ }^{[2]}$ Thermally, this readily undergoes cleavage of $\mathrm{CO}$ to give the $60 \mathrm{e}$ pseudocubane 11. Photochemically, however, it can be transformed in the presence of sulfur into $12 .{ }^{[2]}$ From a structural point of view

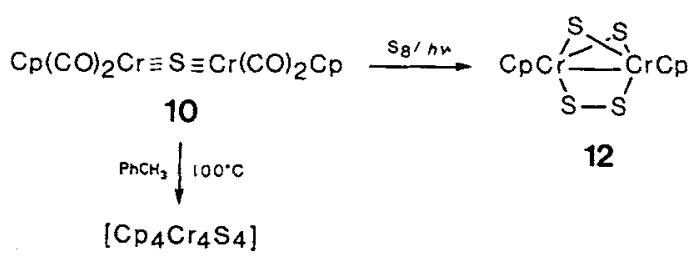

11

complex 12 has the same ligand set as the vanadium complex 3. Formally, $\mathbf{1 2}$ (structure type $\mathbf{A}$ in Scheme 1) is related to 9 (structure type $\mathrm{E}$ ) through a $90^{\circ}$ rotation of the $\mathrm{S}_{2}$ bridge (in contrast to the analogously built Mo sulfides (see Section 2.2.2) 9 and 12 are configurationally stable). Although the two complexes differ in their total electron count by four electrons, their magnetic behavior is very similar.

Also conceivable would be the existence of $\left[\mathrm{Cp}_{2} \mathrm{Cr}_{2}-\right.$ $\left.\left(\mu_{1}, \eta^{2}-S_{2}\right)(\mu-S)\right]$, an even more sulfur-deficient compound than 9 . The isoelectronic dimethylthiolato complex 13 is al-

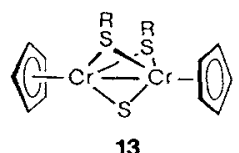

ready known. It shows antiferromagnetic behavior and serves as starting material for the synthesis of numerous S-bridged cluster compounds. ${ }^{[29]}$

\subsubsection{Cyclopentadienyl Sulfides and Selenides of Mo and $W$}

Since the $\mathrm{M}-\mathrm{M}$ triple bond in $\left[\mathrm{Cp}^{(*)} \mathrm{M}(\mathrm{CO})_{2}\right]_{2}$ when $\mathrm{M}=\mathrm{Mo}$ and $\mathrm{W}$ is generally more reactive than that when $\mathrm{M}=\mathrm{Cr},{ }^{[30]}$ the 'harvest' of sulfur-containing compounds is naturally richer. In contrast to the Cr system, even Se- und Te-containing compounds are occasionally isolated. As far as results up to now indicate, there are parallels between the reactivity of $\mathrm{S}$ and $\mathrm{Se}$, while $\mathrm{Te}$ is distinctly less reactive. Particularly striking is the control of the course of reaction by the nature of the cyclopentadienyl ligand (Scheme 4), whereby steric effects may largely be decisive.

$\left[\mathrm{CpMo}(\mathrm{CO})_{2}\right]_{2}$ reacts with substoichiometric amounts of sulfur to give 14 , whose cation contains an $\mathrm{Mo}_{3} \mathrm{~S}$ tetrahedron. ${ }^{[31]}$ In contrast, with sulfur in excess the insoluble compound $\mathbf{1 5}$ is formed. ${ }^{[31-33]}$ The formulation of $\mathbf{1 5}$ as a polymer would appear justified insofar as it can be converted under mild conditions with $\mathrm{H}_{2}{ }^{[34]}$ or $\mathrm{LiEt}_{3} \mathrm{BH}$ into the soluble hydrogensulfido-complex $16 .^{[35]}$ 


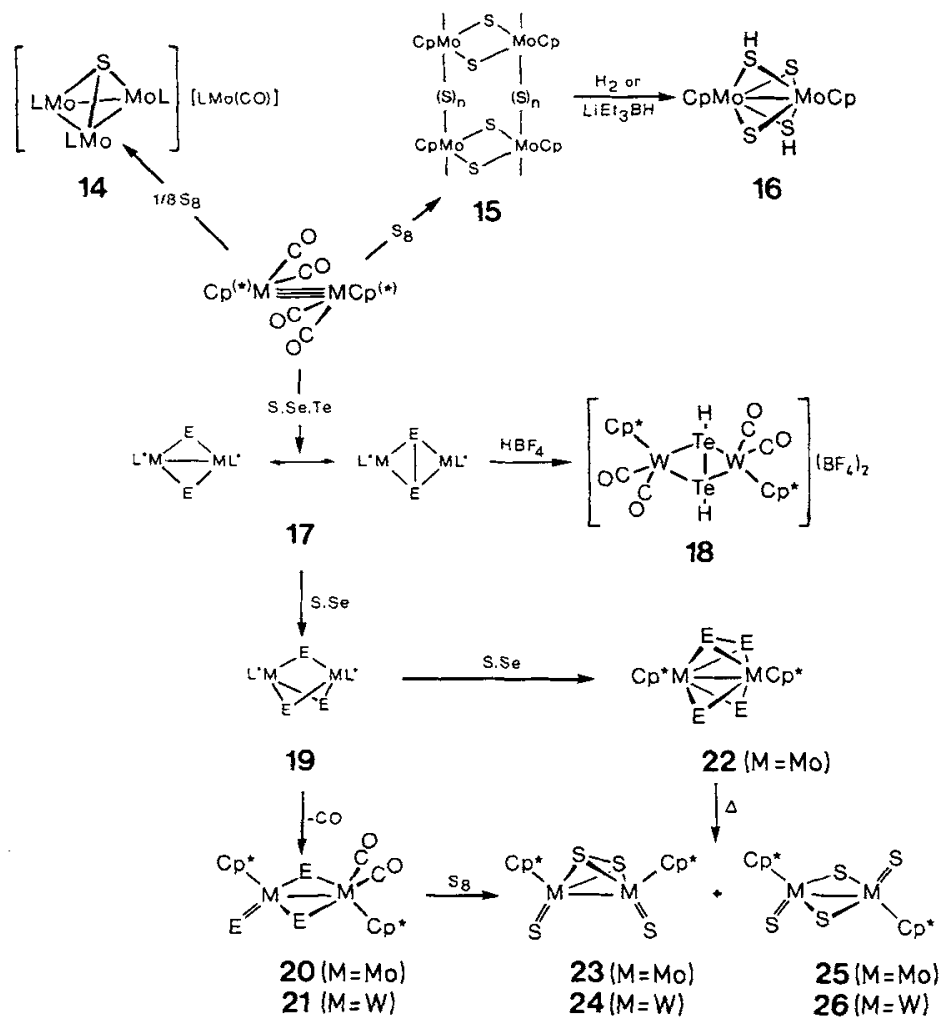

Scheme 4. Overview of the reactions of the chalcogens $\mathrm{S}, \mathrm{Se}$ and $\mathrm{Te}$ with $\left[\mathrm{Cp}^{(*)} \mathrm{M}\left(\mathrm{CO}_{2}\right)\right]_{2}\left(\mathrm{M}=\mathrm{Mo}, \mathrm{W} ; \mathrm{L}=\mathrm{Cp}(\mathrm{CO})_{2}, \mathrm{~L}^{*}=\mathrm{Cp}^{*}(\mathrm{CO})_{2}\right) .19-22: \mathbf{a}, \mathrm{E}=\mathrm{S}$; b, $\mathrm{E}=\mathrm{Se}$. X-ray structurally characterized complexes shown in bold print.

As demonstrated by the occurrence of the kinetically labile di- and tri-chalcogen products 17 and 19 in the reaction of $\left[\mathrm{Cp} * \mathrm{M}(\mathrm{CO})_{2}\right]_{2}(\mathrm{M}=\mathrm{Mo}, \mathrm{W})$ with condensed sulfur or selenium vapor at low temperatures, there must be a stepwise addition of chalcogen fragments to the $M \equiv M$ bonds. ${ }^{\left[{ }^{66]}\right.}$ In contrast, in order to introduce the much less reactive Te the reaction must be carried out at the temperature of boiling THF. The intermediate 17, for which there are two conceivable isomeric forms, can in the case of the $\mathrm{W}-\mathrm{Te}$ compound be captured as a stable complex salt 18 by double protonation. This contains the unusual $\mathrm{Te}_{2} \mathrm{H}_{2}$ ligand. ${ }^{[36]}$

The formation of the complexes 20 and 21 from 19 can be interpreted in terms of an intramolecular rearrangement of the E-ligand framework with partial $\mathrm{CO}$ elimination and formation of an $\mathrm{M}-\mathrm{M}$ bond. 21 a is the first structurally characterized complex whose sulfur bridges are not symmetrical owing to the unusual polarization of the molecule. ${ }^{[37]}$ Whereas the CO ligands of the Mo-intermediates 19 $(\mathrm{M}=\mathrm{Mo})$ and $\mathbf{2 0}$ are relatively easily substituted by sulfur or selenium $\left(45^{\circ} \mathrm{C}\right.$, toluene $)$, the $\mathrm{W}$-complex 21 a reacts only with $\mathrm{S}_{8}$ under substantially more drastic conditions $\left(115^{\circ} \mathrm{C}\right)$ to give well defined complexes. ${ }^{[37,38]} 23-26$ are the thermally most stable complexes of the whole synthetic sequence. In agreement with this, $\mathbf{2 2}$ a isomerizes in solution to give $\mathbf{2 3}$ and $25 .{ }^{[37]}$ Whereas the transformation $22 \mathrm{a} \rightarrow \mathbf{2 3}$ can be described as an opening of both monosulfur bridges, the reaction $22 \mathrm{a} \rightarrow \mathbf{2 5}$ requires the additional cleavage of the $\eta^{2}$-bridge. ${ }^{[39]}$ Interestingly, the entire process is photochemically reversible, since irradiation of any one isomer gives the two other isomers. ${ }^{[40]}$
Although even more $\left[\mathrm{Cp}_{2}^{(*)} \mathrm{Mo}_{2} \mathrm{~S}_{4}\right]$ isomers are conceivable (cf. Scheme 1 and Ref. [41]), the reaction products derived from the reaction of $\left[\mathrm{CpMo}(\mathrm{CO})_{3} \mathrm{H}\right]$ with methylthiirane ${ }^{[42]}$ or $\left[\mathrm{Cp} \mathrm{p}^{*} \mathrm{Mo}(\mathrm{CO})_{3} \mathrm{H}\right]$ with $\mathrm{S}_{8}{ }^{[33]}$ belong, just like $\left[\mathrm{Cp}^{\prime}{ }_{2} \mathrm{Mo}_{2} \mathrm{~S}_{4}\right]^{\left[3^{3}\right]}$ to structural type $\mathbf{H}$ (Scheme 1 ), which is also realized in $\mathbf{2 5}$.

A comparison of the structures of $22 \mathrm{a}^{[37]}$ and $25^{[33]}$ reveals a 'clamping' effect of the bridging ligands in $22 \mathrm{a}$ : the formal Mo-Mo bond orders ( 2 for 22 a, 32 valence electrons (VE) and 3 for 25, $30 \mathrm{VE}$ ) contradict the observed Mo-Mo distances of 2.599 and $2.905 \AA$, respectively. On the other hand, the Mo-S bridging bonds of 25 are on average ca. $0.06 \AA$ shorter than in $22 \mathrm{a}$, which could point to a delocalization of the electrons of the bridging sulfur atoms in 25 . Such a delocalization is further supported by the distinctly lower nucleophilicity found for $25^{[23]}$ compared to that for $22 \mathbf{a}^{[23]}$

An interesting by-product of the reaction of $\left[\mathrm{Cp} * \mathrm{Mo}(\mathrm{CO})_{3} \mathrm{H}\right]$ with $\mathrm{S}_{8}$ is 27 , which contains three different types of $\mathrm{S}_{2}$ ligands (Fig. 3), ${ }^{[33]}$ including the seemingly rare nonplanar $\eta^{1}-\mathrm{S}_{2}$ bridge ${ }^{[4]}\left(\mathrm{Mo}-\mathrm{S} 1-\mathrm{S1}^{\prime}-\mathrm{Mo}^{\prime}\right)$.

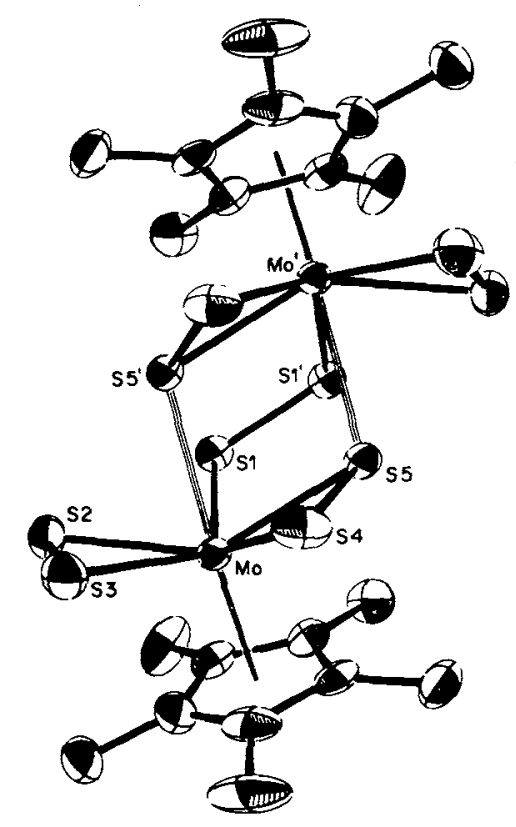

Fig. 3. Structure of $\left[\mathrm{Cp}_{2}^{*} \mathrm{Mo}_{2} \mathrm{~S}_{10}\right] 27$ in the crystai [33].

\subsubsection{Cyclopentadienyl Oxo Complexes}

Even from the relatively few examples presented here (see Scheme 5) it can be seen that - with the exception of $\left[\mathrm{Cp}_{4} \mathrm{Cr}_{4} \mathrm{O}_{4}\right]^{[43]}$ prepared by E. O. Fischer et al.-Cp-complexes of the $\mathrm{Cr}$ triad containing exclusively $\mathrm{O}$-ligands have the same composition $\left[\mathrm{Cp}_{2}^{(*)} \mathrm{M}_{2} \mathrm{E}_{n}\right](\mathrm{n}=4,5)$ as their S-homologues. However, they differ considerably in many structural respects. One reason for this could be that the formal oxidation state of the metal center in the complexes with oxo ligands $\left(\mathrm{Cr}^{\mathrm{V}}\right.$ in $29^{[45]}, \mathrm{Mo}^{\mathrm{VI}}$ in $\left.31^{[45-47]}\right)$ is frequently higher than in the complexes of the usual chalcogens. The only compound which can be directly derived from an already known sulfur complex, namely 25 , is $\left[\mathrm{Cp}_{2} \mathrm{Mo}_{2}-\right.$ $\left.(\mu-\mathrm{O})_{2} \mathrm{O}_{2}\right] 28$ with the structural type $\mathbf{H}$ (Scheme 1). ${ }^{[44]}$ 


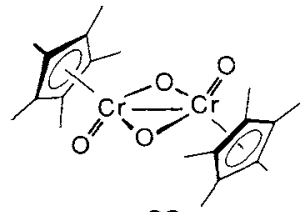

29

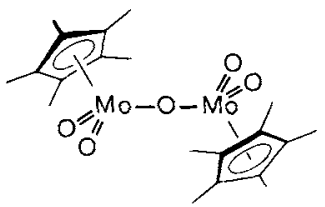

31
30

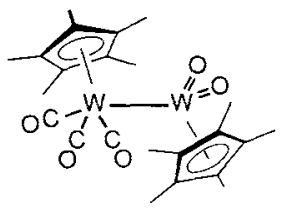

32

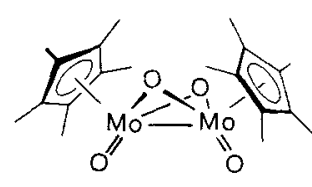

Scheme 5. Examples for the structures of dinuclear $\mathrm{Cp}^{(*)}$ oxo complexes of the chromium triad.

The absence of complexes with $\mathrm{O}_{2}^{2 \ominus}$ ligands is remarkable. Thus, e.g., the transfer of the peroxo ligand of $(t \mathrm{BuNC})_{2} \mathrm{Ni}$ $\left(\mathrm{O}_{2}\right)$ is only possible with the rupture of the $\mathrm{O}-\mathrm{O}$ bond by the $\mathrm{Mo} \equiv$ Mo triple bond of $\left[\mathrm{Cp}^{*} \mathrm{Mo}(\mathrm{CO})_{2}\right]_{2} \cdot{ }^{[48]}$ The resulting complex $\mathbf{3 0}$ shows a folded $\mathrm{Mo}_{2} \mathrm{O}_{2}$ core like that of type $\mathbf{G}$ (Scheme 1). No structural equivalent in the $\left[\mathrm{Cp}_{2}^{(*)} \mathrm{Mo}_{2} \mathrm{~S}_{4}\right]$ system exists for the $\mathrm{Cp}^{*} \mathrm{MoO}_{2}$ moieties present in $\mathbf{3 1}$ and the nearly linear $\mathrm{O}^{2 \ominus}$ ligand that is linking them. ${ }^{[4]}$

There have been contradictory reports on the reaction of $\left[\mathrm{Cp} * \mathrm{~W}(\mathrm{CO})_{2}\right]_{2}$ with $\mathrm{O}_{2}$ : At first two products of the composition $\left[\mathrm{Cp}_{2}^{*} \mathrm{~W}_{2}(\mathrm{CO})_{2} \mathrm{O}_{2}\right]$ and $\left[\mathrm{Cp}_{2}^{*} \mathrm{~W}_{2} \mathrm{O}_{4}\right]$ were reported, ${ }^{[49]}$ but then, in another experiment, the substitution of only one CO group could be established. ${ }^{[50]}$ The X-ray structural analysis of $\mathbf{3 2}$ shows that, owing to the mixed oxidation states of its $\mathrm{W}$ atoms, this complex has a structure to some extent related to that of $\left[\mathrm{Cp}_{2}^{*} \mathrm{~W}_{2}(\mathrm{CO})_{2} \mathrm{~S}_{3}\right] 21 \mathrm{a}^{[37]}$

Complexes which contain both oxo and thio ligands are accessible by reaction of the $\left[\mathrm{Cp}_{2}^{*} \mathrm{Mo}_{2} \mathrm{~S}_{4}\right]$ isomers $22 \mathrm{a}, 23$ and 25 with atmospheric oxygen. ${ }^{[33,51,52]}$ The progress of the reaction can be monitored quite well by ${ }^{95} \mathrm{Mo}-\mathrm{NMR}$ spectroscopy, since the molybdenum centers suffer a shielding effect of $\Delta \delta=400-600$ by introduction of oxygen. ${ }^{[53]}$ The final products $\mathbf{3 3}$ are, according to X-ray structural

$\left[\mathrm{Cp}_{2}^{*} \mathrm{Mo}_{2} \mathrm{~S}_{4}\right] \stackrel{\mathrm{O}_{2}}{\longrightarrow}\left[\mathrm{Cp}_{2}^{*} \mathrm{Mo}_{2} \mathrm{~S}_{4-\mathrm{n}} \mathrm{O}_{\mathrm{n}}\right]+\left[\mathrm{Cp}_{2}^{*} \mathrm{Mo}_{2} \mathrm{~S}_{4}\right] \cdot \mathrm{SO}_{3}$

$22 a$

33. $n=1,2$

34

analyses, clearly of the structural types $\mathbf{G}$ and $\mathbf{H}$ (Scheme 1). The oxo ligands are always terminal, i.e. there are always two $S^{2 \ominus}$ bridges present. Prerequisite for such a reaction with oxygen at the metal center (examples for an oxidation of the sulfur ligands have been well documented ${ }^{[54]}$ ) is obviously the presence of terminal sulfido or selenido ligands. Consistent with the course of the reaction of $22 \mathrm{a}$ with $\mathrm{O}_{2}$ is that the dioxo complex $s y n-\left[\mathrm{Cp}_{2}^{*} \mathrm{Mo}_{2}(\mu-\mathrm{Se})_{2} \mathrm{O}_{2}\right]$ can be structurally characterized (type $\mathbf{G}$ ), whereas this has not been possible for complexes with terminal $\mathrm{Mo}=\mathrm{Se}$ moieties. $^{[36,38]}$

The sulfur released in the reaction of $22 \mathrm{a}, 23$ and 25 with $\mathrm{O}_{2}$ can be isolated in the form of an $\mathrm{SO}_{3}$-adduct to the starting compound. It is assumed, however, that in such a reaction the complex with the most nucleophilic sulfur bridges, 22 a, is employed. Consistent with the comparatively large S-S distance (2.168(2) $\AA$ ), 34 also chemically resembles

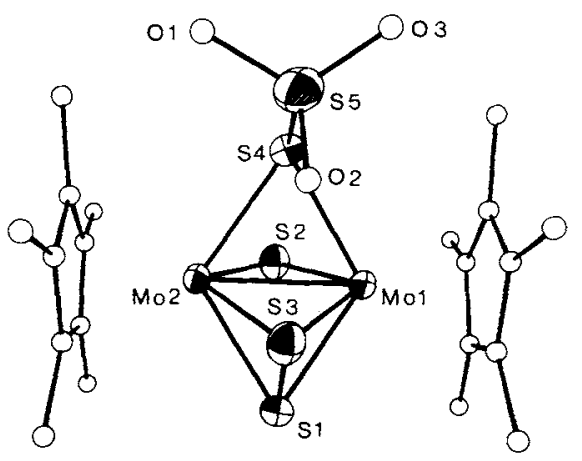

Fig. 4. Structure of 34 in the crystal.

an $\mathrm{SO}_{3}$-adduct of the $\mathrm{S}^{2 \ominus}$ bridge rather than a complex with an $\eta^{1}$-thiosulfato bridge. ${ }^{[52 a, 55]}$ Further information about the mechanism of the reaction can be found in Section 3.4.

\subsection{Cyclopentadienyl Chalcogenides of Mn and Re}

Generally applicable methods for the preparation of chalcogen-rich complexes of $\mathrm{Mn}$ and $\mathrm{Re}$ have not yet been developed. Thus, the reaction of $\mathrm{S}, \mathrm{Se}$ and $\mathrm{Te}$ with $[\mathrm{Cp}$ $(\mathrm{CO})_{2} \mathrm{ML}$ ( $\mathrm{M}=\mathrm{Mn}, \mathrm{Re} ; \mathrm{L}=$ thf, $\left.\mathrm{Et}_{2} \mathrm{O}\right)$ leads only to monoand dichalcogen-bridged products of the $\mathrm{CpM}(\mathrm{CO})_{2}$ fragment. ${ }^{[56]}$ With regard to the subject of this review these complexes are somewhat of a 'dead end', since they do not react any further with chalcogens. The only structurally characterized complex with a higher sulfur content is $[\{\mathrm{CpRe}-$ $\left.(\mathrm{CO})\}_{2} \mathrm{~S}_{5}\right], 35$. This contains a puckered seven-membered ring (Fig. 5), in which an $\mathrm{S}_{2}$ bridge and an $\mathrm{S}_{3}$ bridge connect two $\mathrm{CpRe}(\mathrm{CO})$ moieties. ${ }^{[57]}$ Thus, each Re center has only 16 valence electrons.

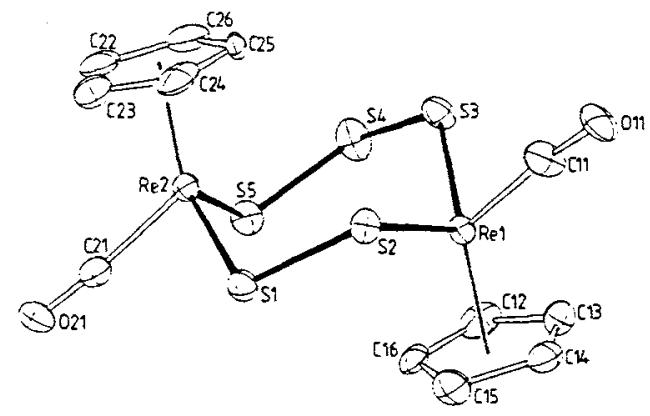

Fig. 5. Structure of $\mathbf{3 5}$ in the crystal [57].

Two CO-free dinuclear complexes of the composition $\left[\mathrm{Cp}_{2}^{*} \mathrm{Mn}_{2} \mathrm{~S}_{4}\right]$ have been prepared from the reactions of $\mathrm{Cp}_{2}^{*} \mathrm{Mn}$ and $\mathrm{Cp}_{2}^{*} \mathrm{Mn}_{2}(\mu-\mathrm{CO})_{3}(M n \equiv M n)$, respectively, with $S_{8}$. The elucidation of the structures of these extremely airsensitive compounds still proves to be quite a challenge. ${ }^{[6]}$ $\left[\mathrm{Cp}_{2}^{*} \mathrm{Re}_{2} \mathrm{~S}_{4}\right]$ is reported to be obtained upon reaction of $\mathrm{Cp}^{*} \mathrm{ReOCl}_{2}$ with $\left(\mathrm{Me}_{3} \mathrm{Si}\right)_{2} \mathrm{~S}$, but this too requires better 
structural characterization. ${ }^{[7]}$ The oxygen homologue $\left[\mathrm{Cp}_{2}^{*} \mathrm{Re}_{2} \mathrm{O}_{4}\right]$ (structural type $\mathrm{H}$, Scheme 1) is a typical example of how the chemistry exhibited by $\mathrm{O}$ - and $\mathrm{S}$-complexes differs. It can be obtained by careful deoxygenation of $\mathrm{Cp} * \mathrm{ReO}_{3}$ and represents a preparatively important and very reactive intermediate. ${ }^{[7 c, 58]}$

\subsection{Cyclopentadienyl Sulfides of Fe and $\mathrm{Ru}$}

Sulfur-rich cyclopentadienyliron complexes have so far only been prepared from $\left[\mathrm{Cp}^{(*)} \mathrm{Fe}(\mathrm{CO})_{2}\right]_{2}$ and elemental sulfur. Scheme 6 covers the differing types of influence exhibited by the substituents on the $\mathrm{Cp}^{(*)}$ ring in the thermal reac-

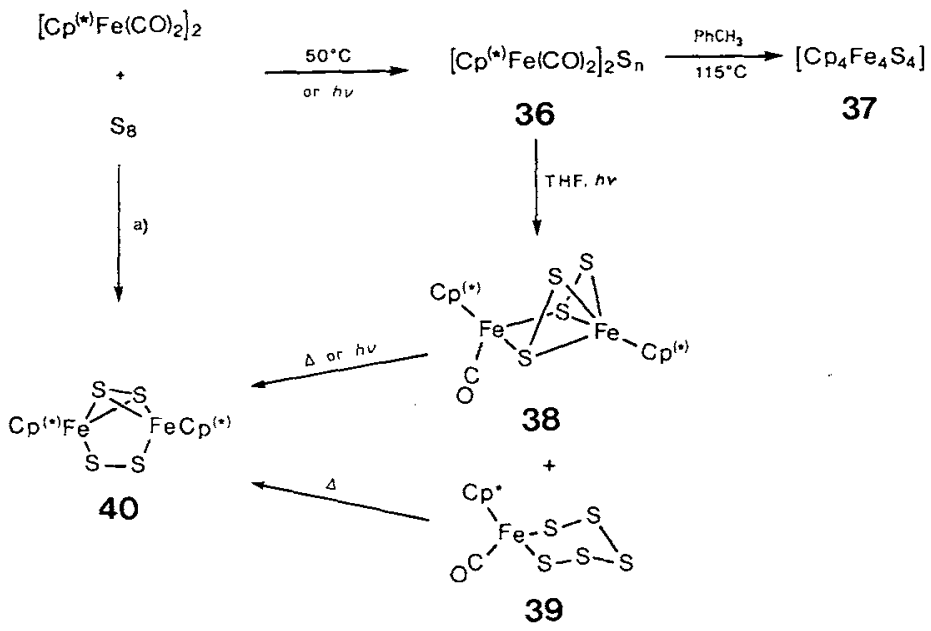

Scheme 6. Overview of the reactions in the system $\left[\mathrm{Cp}^{(*)} \mathrm{Fe}(\mathrm{CO})_{2}\right]_{2}$ /sulfur. a) Toluene, $115^{\circ} \mathrm{C}$, only starting from $\left[\mathrm{Cp} * \mathrm{Fe}(\mathrm{CO})_{2}\right]_{2}$.

tion: when $C \mathrm{p}^{(*)}=\mathrm{Cp}$ the 60 e heterocubane $37^{[32,59]}$ is obtained, whereas when $\mathrm{Cp}^{(*)}=\mathrm{Cp}^{*}$ one obtains the complex $40\left(\mathrm{Cp}^{*}\right)^{[60]} \cdot 40(\mathrm{Cp})$ can, in contrast, only be prepared photochemically. ${ }^{[61]}$ Both complexes $\mathbf{4 0}$ exhibit an interesting structural feature in that two $\eta^{1}-S_{2}$ and $\eta^{2}-S_{2}$ bridges are found perpendicular to each another. ${ }^{[60,611}$ These diamagnetic molecules (34 valence electrons from $2 \mathrm{Cp}^{(*)}+\eta^{1}-\mathrm{S}_{2}$ and $\eta^{2}-S_{2}$ bridges $+2 \mathrm{Fe}=10+2+6+16$ ) have relatively large $\mathrm{Fe}-\mathrm{Fe}$ distances (ca, $3.50 \AA$ ) and shortened $\mathrm{Fe}-\mathrm{S}$ distances. The latter fact in particular proves that there is increased $\pi$-donation from the $\eta^{1}-S_{2}$ ligand coplanar to the $\mathrm{Fe}-\mathrm{Fe}$ vector. The mixing of the sulfur $\mathrm{p}_{\mathrm{x}}$-orbitals perpendicular to the $\mathrm{Fe}_{2} \mathrm{~S}_{2}$ plane with a set of metal d-orbitals of suitable symmetry may explain this effect. ${ }^{[621}$

The products 36 derived from insertion of sulfur into the $\mathrm{Fe}-\mathrm{Fe}$ bond are of intermediate character, of which the derivatives with $\mathrm{Cp}^{(*)}=\mathrm{Cp}$ can even be isolated. $36(\mathrm{Cp}$, $\mathrm{n}=3$ ) can be converted into 37 in boiling toluene, ${ }^{[631} 36(\mathrm{Cp}$, $\mathrm{n}=5$ ) reacts photochemically in THF solution to give $38(\mathrm{Cp})$, which in solution exists in three isomeric forms, of which that given in Scheme 6 has been characterized by an $\mathrm{X}$-ray structure analysis. ${ }^{[61 \mathrm{a}]}$

Recently, the permethylated intermediates $38\left(\mathrm{Cp}^{*}\right)$ and 39 formed during the photolytic preparation of $40\left(\mathrm{Cp}^{*}\right)$ could also be isolated. ${ }^{[64]}$ In contrast to 40,39 is paramagnetic (ESR signal at $g=2.056(3)$ ).
Since $\left[\mathrm{Cp} * \mathrm{Ru}(\mathrm{CO})_{2}\right]_{2}$ dissociates easily under photochemical conditions to give reactive $17 \mathrm{e}$ fragments, ${ }^{[65]}$ it seems likely that the mechanism for the uptake of $S_{8}$ is radical in nature. ${ }^{[6]}$ The primarily formed compound is the tetrasulfido-bridged complex 41 (Scheme 7). This is either stabilized

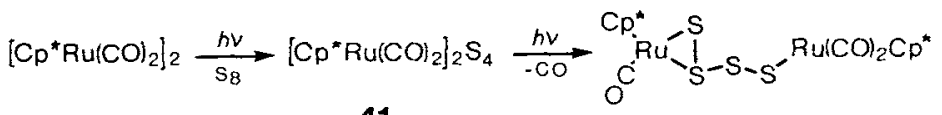

41

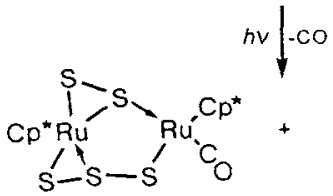

43

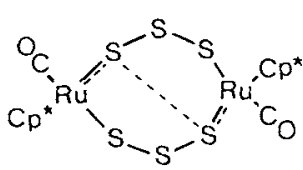

44
Scheme 7. Overview of the reactions in the system $\left[\mathrm{Cp} * \mathrm{Ru}(\mathrm{CO})_{2}\right]_{2} /$ sulfur.

intramolecularly in the form of $\mathbf{4 2}$ with elimination of $\mathrm{CO}$ or reacts further to give the sulfur-rich compounds 43 and 44. ${ }^{[67]}$ In the course of the latter process an $S_{4}$ bridge is broken down and the sulfur fragments that are released are apparently so reactive that they recombine to form a second bridging ligand. In this sense the formation of 43 and 44 is favored by the addition of $\mathrm{S}_{8}$. Under thermal conditions (toluene $115^{\circ} \mathrm{C}$ ) only $\mathbf{4 1}$ and 43 are formed. The structure of 43 can be described as a $\mathrm{Ru}_{2} \mathrm{~S}_{3}$-ring with two sulfur atoms bridging two adjacent $\mathrm{Ru}-\mathrm{S}$ bonds (Fig. 6), i.e. the sulfur

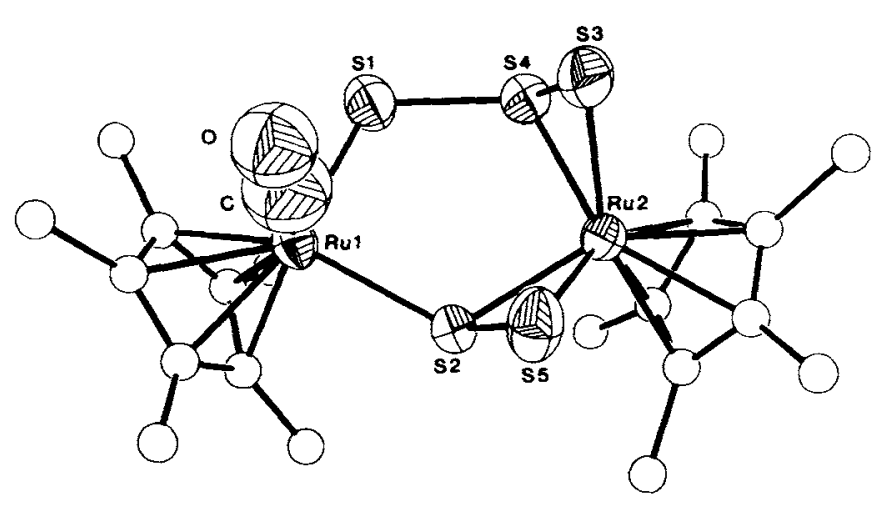

Fig. 6. Structure of $\mathbf{4 3}$ in the crystal.

bridges are effectively pure $\sigma$-donors. The assumption of a folded eight-membered ring in 44 , in which two $S_{3}$-ligands bridge the $\mathrm{Cp}$ * $(\mathrm{CO}) \mathrm{Ru}$ centers, is based on an analogy to the structurally characterized $\left[\left\{\mathrm{Cp}^{\prime} \mathrm{RuPPh}_{3}\right\}_{2} \mathrm{~S}_{6}\right]$, which can be prepared from $\left[\mathrm{Cp}^{\prime}{ }_{2} \mathrm{Ru}_{2}\left(\mathrm{PPh}_{3}\right)_{4} \mathrm{~S}_{2}\right]^{2 \oplus}$ and $\mathrm{S}_{6}^{2 \ominus}$. ${ }^{68 \mathrm{I}} \mathrm{Com}-$ pared to 43 , there are rather different bonding modes, e.g. a bicyclic $\mathrm{Ru}_{2} \mathrm{~S}_{6}$ core as a consequence of relatively important transannular S-S interactions $\left(d_{\mathrm{s}-\mathrm{s}} 2.77 \AA\right)$. Concomittantly, the different $\mathrm{Ru}-\mathrm{S}$ distances $(\Delta d=0.11 \AA$ ) prove that there is an additional $\pi$-donor stabilization of the Ru centers by one $\mathrm{S}$-atom in each case.

With $36(\mathrm{Cp}, \mathrm{n}=4)$ and 5 as examples it could be shown that complexes with polysulfido ligands tend to undergo 
thermal decomposition with the formation of clusters. In contrast to this the metal-sulfur rings in 43 and 44 are so stable that up to now no way has been found to convert them, e.g., into the Ru-analogue of $\mathbf{4 0}$. In this connection it is hard to explain why just a slight modification of the substituents of the $\mathrm{Cp}$ ring has such a large effect on the reaction: $\left[\left(\mathrm{EtC}_{5} \mathrm{Me}_{4}\right)_{2} \mathrm{Ru}_{2}(\mathrm{CO})_{4}\right]$ reacts with $\mathrm{S}_{8}$ in boiling toluene to give $\left[\left(\mathrm{EtC}_{5} \mathrm{Me}_{4}\right)_{2} \mathrm{Ru}_{2} \mathrm{~S}_{4}\right] \mathbf{4 5}$ (structure type $\mathrm{B}$ ) and other still not fully characterized $\mathrm{CO}$-free products. ${ }^{[69]}$

It is known from the higher sulfur homologues, that Se can be inserted into the $\mathrm{Fe}-\mathrm{Fe}$ bond of $\left[\mathrm{CpFe}(\mathrm{CO})_{2}\right]_{2}$. The number of bridging members in the products $\left[\left\{\mathrm{CpFe}(\mathrm{CO})_{2}\right\}_{2}(\mu-\right.$ $\left.\mathrm{Se})_{\mathrm{n}}\right]$ appears, however, to be limited to $\mathrm{n}=1$ and 2 , respectively. ${ }^{[70]}$ An excess of Se leads to the $60 \mathrm{e}$ heterocubane $\left[\mathrm{Cp}_{4} \mathrm{Fe}_{4} \mathrm{Se}_{4}\right] .{ }^{[71]}$

\subsection{Cyclopentadienyl Chalcogenides of $\mathrm{Co}$ and $\mathrm{Rh}$}

The substrates from the Co triad that were chosen for reactions with chalcogens were the $\mathrm{M}=\mathrm{M}$ double bonded dimers $\left[\mathrm{Cp}^{*} \mathrm{M}(\mathrm{CO})\right]_{2}(\mathrm{M}=\mathrm{Co}, \mathrm{Rh})$. These react with sulfur and selenium but not Te under mild conditions, finally giving CO-free products which have different structures (46-48), depending on the chalcogen and the metal. 46 has the struc-

$$
\text { }
$$

ture type $\mathbf{D}$ (Scheme 1), in which the two $\eta^{1}, \eta^{2}-S_{2}$ bridges each act as $4 \mathrm{e}$ donors. (Fig. 7 a) ${ }^{[60]}$ In contrast, the molecular structure of 47 contains two $\mathrm{RhS}_{4}$ chelates, which are coupled with formation of a slightly puckered $\mathrm{Rh}_{2} \mathrm{~S}_{3}$ fivemembered ring (Fig. 7b). ${ }^{[72]}$ This asymmetric method of coordination allows the donation of four electrons per ligand and is thus quite interesting, since up to now all bridging $\mathrm{S}_{4}$ ligands have been found to act as $6 \mathrm{e}$ donors coordinated via their terminal atoms. ${ }^{[5]}$ In contrast, two non-bridging $\mathrm{S}_{4}$ chelating ligands are present in $\mathbf{5 1}$ (see Scheme 8), which is the precursor of 47 . The elimination of sulfur from 47 to give a complex analogous to 46 with a $\mathrm{Rh}_{2} \mathrm{~S}_{4}{ }^{2 \oplus}$ core has not yet been successfully carried out - although a core of this type is found in [(triphos) $\left.{ }_{2} \mathrm{Rh}_{2} \mathrm{~S}_{4}\right]\left(\mathrm{BPh}_{4}\right)_{2} 54 .^{[73]}$

The 36 e complexes $48(\mathrm{M}=\mathrm{Rh}, \mathrm{Co})$ may be regarded as triple-decker complexes of a special kind. ${ }^{[74]}$ The middle deck is a planar pseudo-five-membered ring which is $\sigma$ bound through three coordination sites and consists of a $\mathrm{Se}^{2 \ominus}$ ligand and $\mathrm{S} \mathrm{Se}_{4}^{2 \ominus}$ ligand (Fig. 7c). The relatively short intramolecular $\mathrm{Se} \cdots$ Se distances of about $3.10 \AA$ could be
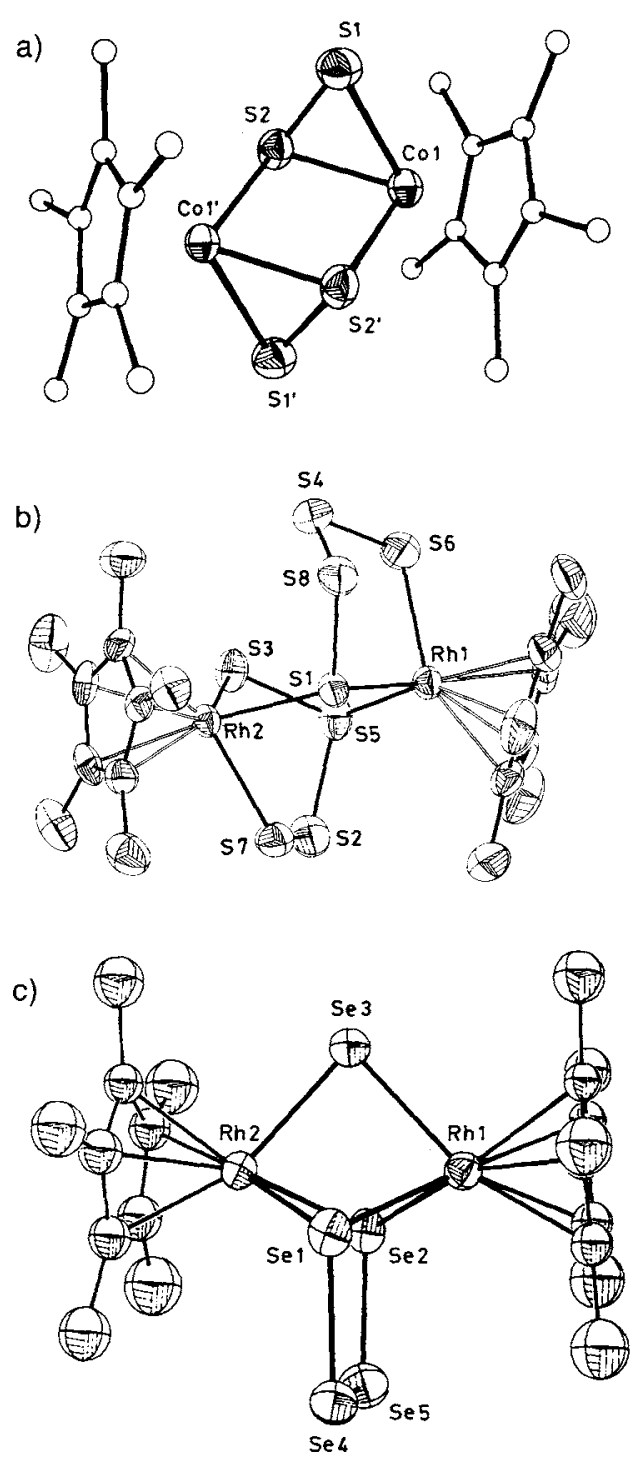

Fig. 7. Structures of a) $\mathbf{4 6}$, b) 47 and c) $48(M=R h)$ in the crystal.

responsible for the stabilization of this bonding system. Weaker intermolecular Van-der-Waals interactions $\left(d_{\mathrm{se}} \cdots \mathrm{se}\right.$ $3.50 \AA$ ) seem to be responsible for the anisotropic orienta-

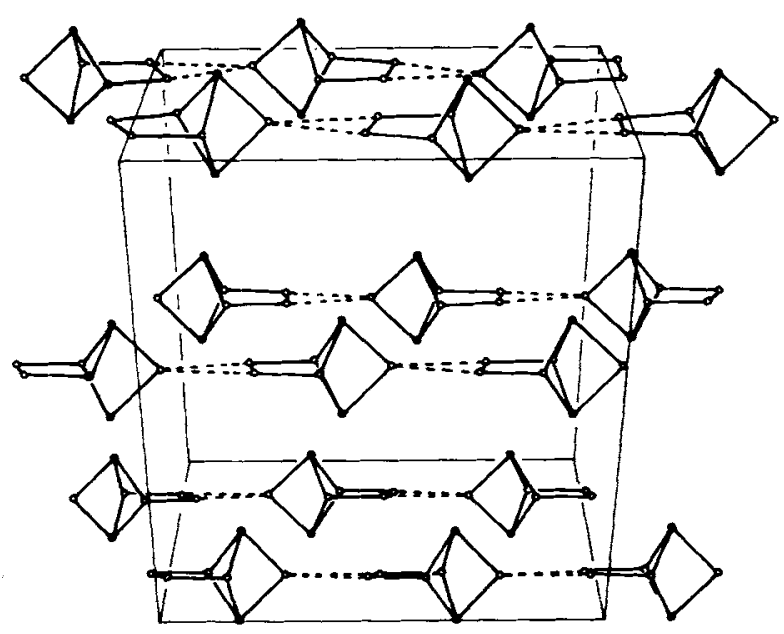

Fig. 8. Unit cell of $48(M=R h)(O=$ Se atoms, $=$ Rh atoms; the Cp* ligands have been omitted for clarity). 
tion of the molecules in the crystal lattice. This is unusual for cyclopentadienyl complexes. All Se atoms lie in one plane, which, due to the parallel $\mathrm{Cp}^{*}$ rings, gives it a compact layer structure (Fig. 8).

Investigations of the mechanism whereby the complexes 46-48 are formed must concentrate above all on evidence for and characterization of the mono- and dichalcogenide adducts at the $M=M$ bond, 49 and $\mathbf{5 0}$ (Scheme 8 ), since the<smiles></smiles>

49

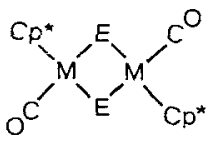

50

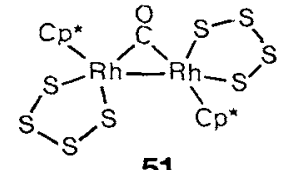

51<smiles></smiles>

52

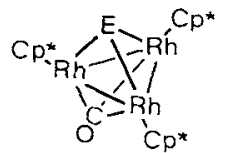

53
Scheme 8 . Intermediates of the reactions of $\left[C \mathrm{p}^{*} \mathrm{M}(\mathrm{CO})\right]_{2}(\mathrm{M}=\mathrm{Co}, \mathrm{Rh})$ with the chalcogens $\mathrm{E}(\mathrm{S}, \mathrm{Se}, \mathrm{Te})$.

incorporation and fragmentation of the chalcogen units occurs so quickly that they can hardly be followed, even by low-temperature IR spectroscopy. ${ }^{[74 \mathrm{bl}}$ The stability of these complexes can certainly be traced to the influence of the central metal (some of the cobalt complexes are so labile that they can only be characterized by IR spectroscopy), but the reactivity of the chalcogen employed is also an important factor. The order of reactivity is $\mathrm{S}_{8} \approx \mathrm{Se}_{8}>\mathrm{Se}_{\mathrm{x}}>\mathrm{Te}$. Due to oxidative addition of sulfur or selenium respectively (tellurium is not sufficiently reactive) at the metal centers of 49 and $\mathbf{5 0}, \mathrm{ME}_{4}$ chelating rings are ultimately formed. Only in the case of the $\mathrm{Co} / \mathrm{S}$ system (46) does the degradation of the $\mathrm{S}_{8}$ ring ultimately give an $\mathrm{MS}_{2}$ unit. A further intermediate $51^{[74 \mathrm{bl}}$ with a symmetrically bridging $\mathrm{CO}$ ligand has been isolated in the $\mathrm{Rh} / \mathrm{S}$ system. Solutions of $\mathbf{5 1}$ eliminate $\mathrm{CO}$ at room temperature with the formation of 47 .

Although it has not yet been directly proved, mononuclear complexes with metal-sulfur double bonds play a key role in the formation of sulfur-bridged binuclear complexes-this is at least true in the case of the $\mathrm{Cp}^{(*)}(\mathrm{CO})_{2} \mathrm{M} / \mathrm{S}_{8}(\mathrm{M}=\mathrm{Mn}, \mathrm{Re})$ systems. ${ }^{[56]}$ The complexes $\mathbf{5 2}$, with noble gas configurations, also come into this category-indirect evidence for their existence has been obtained by studying the manner in which the complex $49(\mathrm{M}=\mathrm{Rh} ; \mathrm{E}=\mathrm{S}, \mathrm{Se})$ disproportionates to give the structurally characterized 48 e clusters $53 .^{[64]}$

\section{Reactions}

\subsection{Tranformations of Mono- and Disulfido Ligands}

Due to their clear structures the complexes of the type $\left[\mathrm{Cp}_{2}^{(*)} \mathrm{M}_{2} \mathrm{~S}_{4}\right]$ are especially suitable for the study of ligand transformations. A special case, limited as yet to Mo and $\mathrm{W}$ complexes, is the opening of a pair of monosulfido bridges to two terminal $\mathrm{M}=\mathrm{S}$ units (Scheme 9). The reverse reaction is not only photochemically possible, it is also induced by $\mathrm{H}_{2}$ or unsaturated organic molecules, giving complexes such as $16^{[33]}$.

During the course of the isomerization $22 a \rightarrow 25^{[37]}$ (Scheme 4) a reductive opening of the $\eta^{2}-S_{2}$ bridge with consequent flattening of the folded $\mathrm{Mo}_{2} \mathrm{~S}_{2}$ four-membered ring was also observed. According to recent experimental findings this reaction could even proceed via a dissociative mechanism. ${ }^{[52 \mathrm{~b}]}$ The bridge opening occurs formally with a change in the metal oxidation state [b) in Scheme 9] represented by Equation (a):

$2 \mathrm{Mo}^{\mathrm{IV}}+\mathrm{S}_{2}^{2 \Theta} \rightarrow 2 \mathrm{Mo}(\mathrm{V})+2 \mathrm{~S}^{2 \Theta}$

The reverse reaction, whose inorganic equivalent is the redox-condensation reaction of oxothiomolybdates and -tungstates $\left[\mathrm{MO}_{\mathrm{n}} \mathrm{S}_{4-\mathrm{n}}\right]^{2 \ominus}(\mathrm{M}=\mathrm{Mo}, \mathrm{W} ; \mathrm{n}=0-2),{ }^{[75]} \mathrm{can}$ be carried out photochemically. a)<smiles>S=[W]N=S1CCCCC1</smiles>

b)

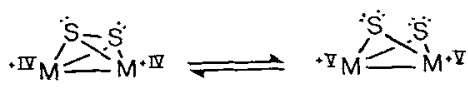

c)

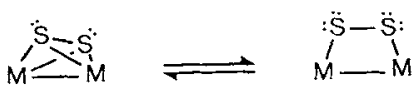

Scheme 9. Transformations of sulfur ligands in $\left[\mathrm{Cp}_{2}^{(*)} \mathrm{M}_{2} \mathrm{~S}_{4}\right]$ complexes. a) and b) $M=M o, W$. c) $M=V, F e$

An elegant possibility of removing any electron deficiency arising at the metal centers, is the rearrangement of a $\mu, \eta^{1}-S_{2}$ ligand to a $\mu, \eta^{2}-S_{2}$ ligand [(c) in Scheme 9 from right to left]. This $90^{\circ}$ rotation, which theoretically ought to be symmetry forbidden, ${ }^{[39]}$ effectively gives the complex four more valence electrons. This explains, for example, why the 26 e complex $\left[\mathrm{Cp}_{2}^{\prime} \mathrm{V}_{2} \mathrm{~S}_{4}\right] 3$ undergoes such a transformation to give the $48 \mathrm{e}$ trinuclear cluster 55 upon addition of an $\mathrm{Fe}(\mathrm{CO})_{3}$ fragment at the monosulfido bridges. ${ }^{[76]}$ In contrast to such chemically induced isomerizations ${ }^{[77]}$ the electron-transfer induced $\eta^{1}-S_{2} \rightarrow \eta^{2}-S_{2}$ isomerization of $\left[\mathrm{Cp}^{*}{ }_{2} \mathrm{Fe}_{2} \mathrm{~S}_{4}\right]$
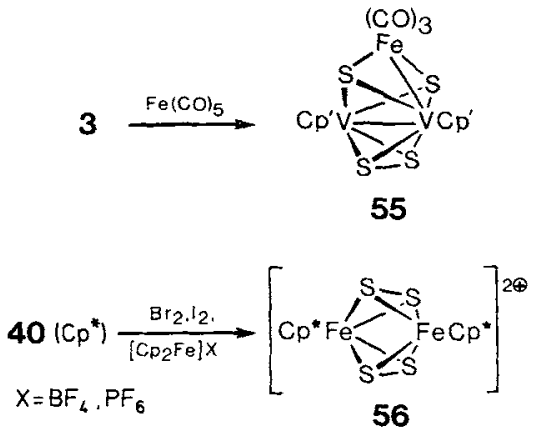

40(C $\mathrm{p}^{*}$, structure type $\left.\mathrm{B}\right)$ on oxidation is reversible - oxidation can be achieved with $\mathrm{Br}_{2}, \mathrm{I}_{2},\left[\mathrm{Cp}_{2} \mathrm{Fe}_{\mathrm{PF}} \mathrm{PF}_{6}\right.$ or even electrochemically, giving the dication 56 with an inert gas configuration. As in $40\left(\mathrm{Cp}^{*}\right)$, the $\mathrm{Fe}-\mathrm{Fe}$ distance in $\mathbf{5 6}$, although 
shortened by ca. $0.7 \AA$ by the clamping effect of the two $\eta^{2}-S_{2}$ bridges, is non-bonding in nature. ${ }^{[78]}$ Careful electrochemical investigations revealed the existence of an intermediate monocation, which quickly disproportionates to give $40\left(\mathrm{Cp}^{*}\right)$ and 56 . Also remarkable is the stabilization of the $\mathrm{S}_{2}$-bridges by the $C \mathrm{P}^{(*)}$-ligands, which, in principle, counteracts their possible elimination. ${ }^{[62]}$

\subsection{Formation of $S-C$ Bonds}

\subsubsection{The Alkylation of Sulfur Bridges}

All sulfur ligands of the $C \mathrm{p}_{2}^{(*)} \mathrm{M}_{2} \mathrm{~S}_{4}$ complexes presented in this paper have lone electron pairs and thus possess nucleophilic properties. Reaction with $\mathrm{CH}_{3} \mathrm{I}$ leads predominantly to alkylation of the monosulfido bridges, whose nucleophilicity is only exceeded by the $\mu, \eta^{1}-\mathrm{S}, \mathrm{S}$ ligand in $\left[\mathrm{Cp}_{2}^{*} \mathrm{Cr}_{2} \mathrm{~S}_{5}\right]$ 8. $^{[23]}$ Sulfur ligands whose lone pairs are withdrawn in order to stabilize the unsaturated metal centers via $\pi$-donation (e.g. in $\mathbf{2 ,} \mathbf{3}, \mathbf{4 0 , 4 5}$ ), are, in contrast, inert to alkylation by $\mathrm{CH}_{3} \mathrm{I}$. The monocationic complexes formed by such alkylation reactions are then susceptible to attack by nucleophiles, e.g. $\mathrm{CH}_{3} \mathrm{Li}^{\left[{ }^{[79]}\right.} \mathrm{By}$ such a reaction sequence, for example, the cis-dithiolato complex $\mathbf{5 8}$ is accessible from $\mathbf{5 7}$ (Scheme 10). ${ }^{[80]}$

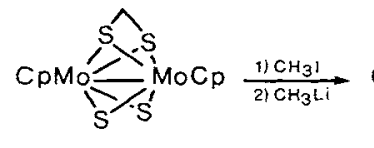

57

$\mathrm{CH}_{3} \mathrm{COBr}_{\mathrm{r}}$

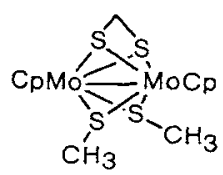

58

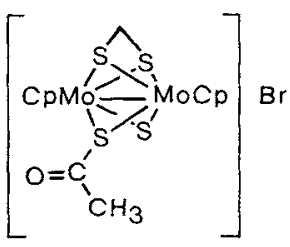

59

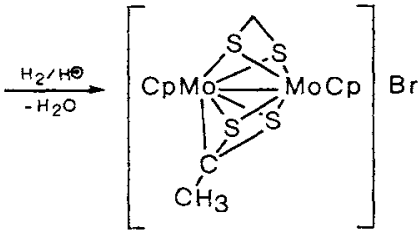

60
Scheme 10. Alkylation and acylation reactions at sulfur bridges using $\mathbf{5 7}$ as example.

In the complex 57, which is accessible by reaction of the bis(hydrogensulfido) complex 16 with $\mathrm{CH}_{2} \mathrm{Br}_{2} / \mathrm{NaOCH}_{3}$, two sulfur bridges are connected by a methylene bridge. ${ }^{[80]}$ Owing to the two remaining cisoid $\mathrm{S}^{2 \ominus}$ bridges, $\mathbf{5 7}$ is without doubt a good model system for the molybdenum sulfide surfaces of commercial hydrotreating catalysts. Examples of alkylation reactions of $\mathbf{5 7}$ include, inter alia, the reductive cleavage of the $\mathrm{C}-\mathrm{Hal}$ bonds of haloesters, acyl halides and vinyl bromides. ${ }^{[811}$ Of the complexes formed in this way the acetyl complex $\mathbf{5 9}$ is especially interesting, since it is able to activate $\mathrm{H}_{2}$ with $\mathrm{HHal}$ elimination and then eliminate water in a complicated reaction sequence after addition of further acid. The complex salt 60 finally formed by this reaction contains a $\mu, \eta^{2}, \eta^{3}$-dithioacetato ligand. Completely analogous to this $\mathrm{C}=\mathrm{O}$ bond cleavage is the evolution of $\mathrm{NH}_{3}$ from
$\mathrm{CH}_{3} \mathrm{CN}$, whereby 60 is again formed ${ }^{[82]}$ Such reactions with expansion of the metal coordination sphere are very rare for the $\left[\mathrm{Cp}_{2}^{(*)} \mathrm{M}_{2} \mathrm{~S}_{4}\right]$-system. However, they show that, under certain circumstances, the central metal can act as a Lewis base.

\subsubsection{Alkenedithiolato Complexes}

It is impossible to arrange the reactions of complexes of the type $\left[\mathrm{Cp}_{2}^{*} \mathrm{M}_{2} \mathrm{~S}_{4}\right]$ with alkynes in a systematic scheme. This is again a consequence of the various reactivities of the sulfur ligands (Scheme 11).

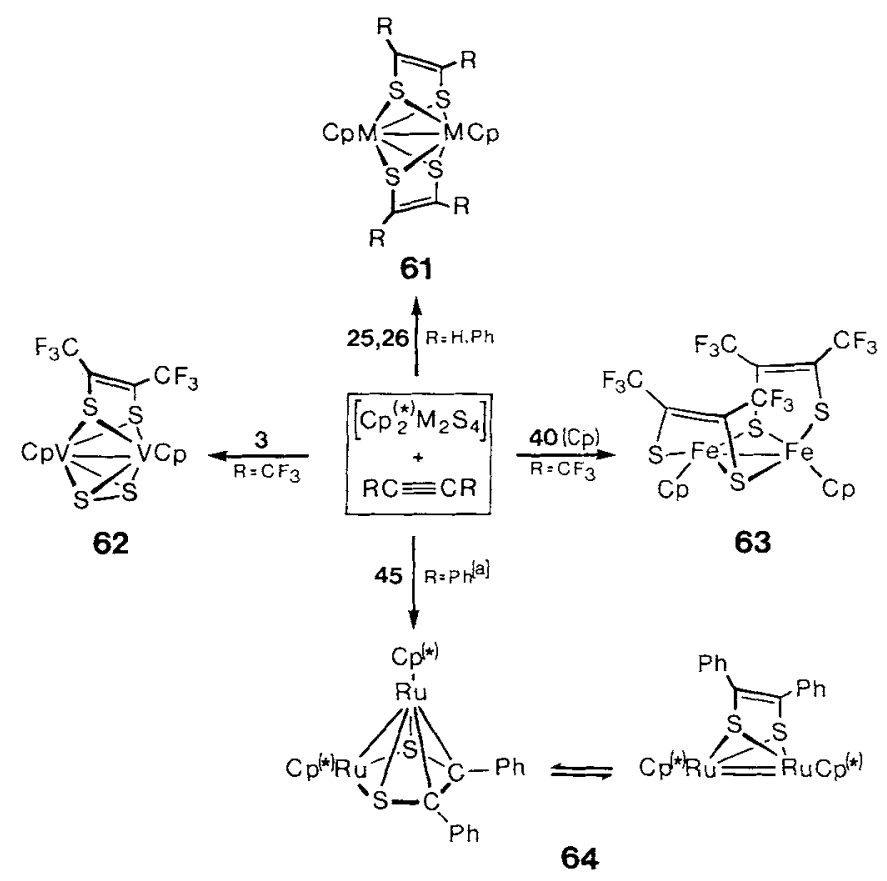

Scheme 11. Overview of the formation of complexes with alkenedithiolato bridges from $\left[\mathrm{Cp}_{2}^{(*)} \mathrm{M}_{2} \mathrm{~S}_{4}\right]$ complexes $\left(\mathrm{Cp} \mathrm{p}^{(*)}\right.$ in $\left.64=n^{5}-\mathrm{C}_{5} \mathrm{Me}_{4} \mathrm{Et}\right)$. [a] Reaction only in the presence of $\mathrm{PBu}_{3}$.

Only the Mo and $W$ complexes 25 and $26^{[33,83]}$ react with unactivated alkynes. The bis(alkenedithiolato) complexes 61 thereby obtained can be reversibly hydrogenated under mild conditions to give bis(alkanedithiolato) complexes. The organic component of the dithiolato ligands is able to undergo exchange reactions with unsaturated hydrocarbons ${ }^{[41,83]}$.

Complexes with $\pi$-donor sulfur ligands react only with electrophilic alkynes. Thus, $\left[\mathrm{Cp}_{2}^{\prime} \mathrm{V}_{2} \mathrm{~S}_{5}\right], \mathbf{2 a}\left(\mathrm{Cp}^{\prime}\right)$ reacts with hexafluorobutyne to give the mononuclear bischelate complex $\left[\mathrm{Cp}^{\prime} \mathrm{V}\left\{\mathrm{SC}\left(\mathrm{CF}_{3}\right)=\mathrm{C}\left(\mathrm{CF}_{3}\right) \mathrm{S}\right\}_{2}\right],{ }^{[151}$ whereas $\left[\mathrm{Cp}_{2}^{\prime} \mathrm{V}_{2} \mathrm{~S}_{4}\right] \mathbf{3}$, with $90^{\circ}$ rotation of the $\eta^{1}-S_{2}$ ligand, affords 62 with a symmetrical alkenedithiolato bridge. ${ }^{[18]}\left[\mathrm{Cp}_{2} \mathrm{Fe}_{2} \mathrm{~S}_{4}\right] 40(\mathrm{Cp})$ reacts with $\mathrm{CF}_{3} \mathrm{C} \equiv \mathrm{CCF}_{3}$ with cleavage of both $\mathrm{S}_{2}$ bridges to give the bisadduct 63, in which the two $\mu, \eta^{1}, \eta^{2}$-alkenedithiolato ligands are $4 \mathrm{e}$ donors. Of the two possible isomers only cis-63 has been structurally characterized.$^{[1 \mathrm{bl}]}$ The $\mathrm{Ru}$ complex $\mathbf{4 5}$, which is isostructural with $\mathbf{4 0}$, (Section 2.4) reacts with $\mathrm{PhC} \equiv \mathrm{CPh}$ only in the presence of the sulfur $\mathrm{ab}$ stracting reagent $\mathrm{PBu}_{3}$ to give the pentagonal-pyramidal nido-cluster $64 .{ }^{1} \mathrm{H}-\mathrm{NMR}$ spectroscopic findings in solution indicate that the equilibrium between the unusual $\mu, \eta^{2}, \eta^{4}$ coordination and a symmetrically bridging $\eta^{2}$-coordination shown in Scheme 11 can be assumed for the cluster $64 .{ }^{[69]}$ 


\subsection{Formation of $\mathrm{S}-\mathrm{H}$ Bonds}

As long ago as 1949 it was shown that chemisorption of $\mathrm{H}_{2}$ on $\mathrm{MoS}_{2}$ occurs with the formation of SH ligands. ${ }^{[84]}$ One such activation of $\mathrm{H}_{2}$ on heterogeneous metal sulfide surfaces has been discussed as a possible step in the mechanism of the HDS catalysis. ${ }^{[85]}$. In this context the complex $\left[\mathrm{Cp}_{2}^{(*)} \mathrm{Mo}_{2} \mathrm{~S}_{2}(\mathrm{SH})_{2}\right](\mathbf{1 6}$; for synthesis see Scheme 4) is of special importance owing to the concomitant presence of sulfido- and mercapto-bridging ligands. For example 16 catalyzes the $\mathrm{H} / \mathrm{D}$ exchange in a $\mathrm{H}_{2} \mathrm{D}_{2}$ mixture, ${ }^{[34]}$ it hydrogenates $\mathrm{N}=\mathrm{N}$ and $\mathrm{C}=\mathrm{N}$ bonds under mild conditions ${ }^{[861}$ and adds thiols with elimination of $\mathrm{H}_{2}$ to give thiolato complexes, and it reacts with $\mathrm{C}_{2} \mathrm{H}_{4}$ and $\mathrm{C}_{2} \mathrm{H}_{2}$, forming alkaneand alkenedithiolato complexes (e.g. 61). ${ }^{[34]}$

An interesting reaction is the reduction of $\mathrm{SO}_{2}$ with 65 to give $\mathrm{H}_{2} \mathrm{O}$ and $\mathrm{S}_{8}$ [Eq. (b)] which may proceed with formation of labile S-S bonds (see Section 3.4). The complex 22a thus

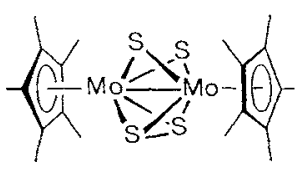

22a

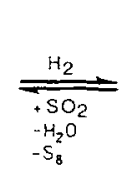
$-S_{B}$

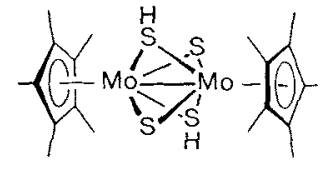

65 formed reacts with $\mathrm{H}_{2}$ with cleavage of the disulfido bridge to give $\mathbf{6 5}$ again. The overall process can thus be formulated as a metal-catalyzed $\mathrm{SO}_{2}$ reduction. ${ }^{[87]}$ Attempts to hydrogenate the $\mathrm{S}_{2}$ ligands in other $\left[\mathrm{Cp}_{2}^{(*)} \mathrm{M}_{2} \mathrm{~S}_{4}\right]$ complexes reveal that Mo is by a long way the most favorable center for such reactions. Thus, reactions of the Cr-complex $\mathbf{9}$, which is isolobal with $\mathbf{2 2} \mathbf{a}$, and its more sulfur-rich precursor $\mathbf{8}$ with $\mathrm{H}_{2}$ only proceed under high pressure and then with the formation of $\left[\mathrm{Cp}_{4}^{*} \mathrm{Cr}_{4} \mathrm{~S}_{4}\right]$. (Although the mechanism of this reaction is still not clear, it could be confirmed that the presence of $\mathrm{H}_{2}$ is essential. $)^{[231}$ In contrast, $\left[\mathrm{Cp}_{2}^{*} \mathrm{Fe}_{2} \mathrm{~S}_{4}\right] 40\left(\mathrm{Cp}^{*}\right)$ is inert to $\mathrm{H}_{2}$ up to 250 bar. ${ }^{[60]}$

\subsection{Formation of S-S Bonds}

As already indicated in Section 2.2.3 one of the products (34) formed upon reaction of 22 a with atmospheric oxygen contains a coordinated $\mathrm{SO}_{3}$ ligand on the monosulfido bridge. The same product could be synthesized in much better yield by the direct reaction of $\mathrm{SO}_{3}$. pyridine with $22 \mathrm{a}$ [Eq. (c)] ${ }^{[88]}$ This reaction can also be used to synthesize new

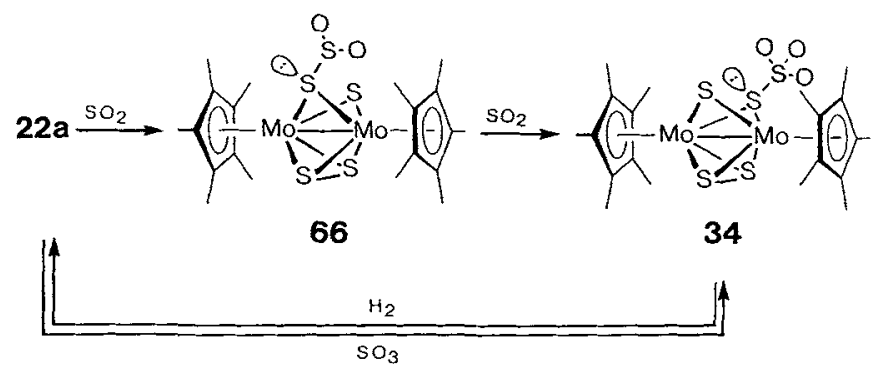

unusual ligands such as $\mu, \eta^{1}-\mathrm{S}_{3} \mathrm{O}_{3}$ in $8 \cdot \mathrm{SO}_{3}{ }^{[24]}$ and $\mu, \eta^{1}$ $\mathrm{SeSO}_{3}$ in $49 \cdot \mathrm{SO}_{3}(\mathrm{M}=\mathrm{Rh}, \mathrm{E}=\mathrm{Se}){ }^{[89]}$

34 can aiso be prepared in a two-step reaction from 22 a and $\mathrm{SO}_{2}$ [Eq. (c)]. Remarkably the initially formed $\mathrm{SO}_{2}$-adduct 66 is oxidized to 34 by $\mathrm{SO}_{2}$ and not by $\mathrm{O}_{2}$-this has been proved using ${ }^{18} \mathrm{O}$-labeling experiments. ${ }^{901}$. During the oxidation elemental sulfur is formed. Results so far would suggest that the oxidation proceeds with inversion at the S-atom, thus indicating the existence of further as yet unidentified intermediates. For the air "oxidation" of $\mathbf{2 2}$ a and similar complexes (above all 8 ) the presence of sulfur, which is easily activated, is essential. ${ }^{[24]}$ The oxidation of $\mathrm{SO}_{2}$ to $\mathrm{SO}_{3}$ by excess $\mathrm{SO}_{2}$ can be assumed not only to occur on the complex but also in solution by a disproportionation reaction. In solution the $\mathrm{SO}_{3}$ being a very strong electrophile is an excellent coordination reagent not only for sulfur but also for other chalcogen ligands as well. ${ }^{[24,88]}$

Since 34 can be reduced to 22 a with $\mathrm{H}_{2}$ [Eq. (c)] and since an excess of $\mathrm{H}_{2}$ causes the formation of $\mathbf{6 5}$, it has been suggested that the processes in Equations (b) and (c) can be summarized in a cycle, ${ }^{[87,901}$ that is as an organometallic variant of the Claus process (oxidation of $\mathrm{H}_{2} \mathrm{~S}$ to $\mathrm{S}$ with atmospheric oxygen).

\subsection{Synthesis of Tri- and Tetranuclear Clusters}

A further outstanding property of a large number of the $\left[\mathrm{Cp}_{2}^{(*)} \mathrm{M}_{2} \mathrm{~S}_{4}\right]$ complexes is their ability to coordinate reactive or unsaturated metal fragments using the lone pairs of the sulfur ligands. Thus, the sulfur ligands enlarge their connectivity from $\mu_{2}$ to $\mu_{3}$ and exceptionally to $\mu_{4}$. Whereas simple

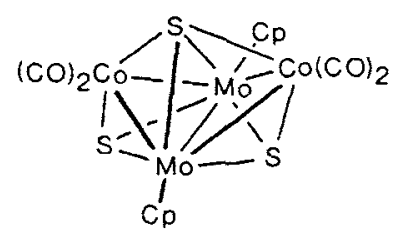

67

adducts can only as a rule be characterized with difficulty, the $48 \mathrm{e}$ trinuclear clusters such as for example $\mathbf{5 5}$ (Section $3.1)$ or 68 are stable enough to be isolated and structurally characterized. ${ }^{[76,91]}$ Particularly characteristic of these $48 \mathrm{e}$ clusters is a trigonal-bipyramidal $\mathrm{M}_{2} \mathrm{M}^{\prime}\left(\mu_{3}-\mathrm{S}\right)_{2}$ framework, the $M-M$ edge of which is spanned by a $\mu, \eta^{2}-S_{2}$ ligand. This arrangement is of special interest as a building block for the construction of multimetallic chains. It is also capable of oxidatively adding a further metal fragment, striving for a cubane type structure with a $\mathrm{M}_{2} \mathrm{M}_{2}^{\prime} \mathrm{S}_{4}$ core. ${ }^{[91,92]}$

A simple and efficient concept for the synthesis of homoand heterometallic clusters containing an $\mathrm{M}_{2} \mathrm{M}_{2}^{\prime} \mathrm{S}_{4}$ core is that developed on the basis of $\left[\mathrm{Cp}_{2}^{*} \mathrm{Cr}_{2} \mathrm{~S}_{5}\right] 8$ (which loses its labile $\mathrm{S}$ atom on reaction) and $\left[\mathrm{Cp}_{2}^{*} \mathrm{Mo}_{2} \mathrm{~S}_{4}\right]$ presented in Equation (d). Starting from any structural framework (E, G or $\mathbf{H}$ ) the $\mathrm{Cr}$ and Mo dimers can, after transformation of all mono- and disulfido-ligands into four-electron donors, ${ }^{[931}$ function as potential $38 \mathrm{e}$ substrate $\left(2 \mathrm{Cp}^{*} \mathrm{M}+4 \mu_{3}-\mathrm{S}=\right.$ 


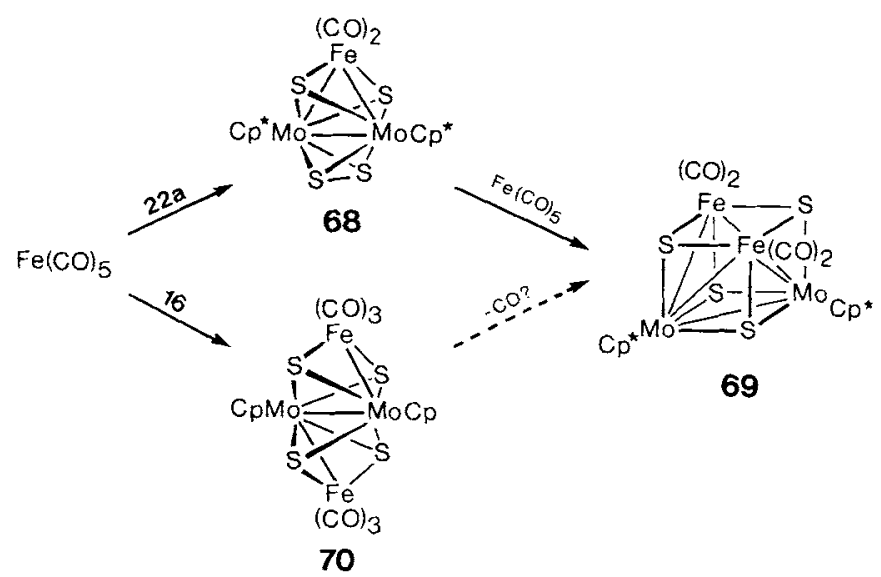

$2 \times 11+4 \times 4$ ). These give $60 \mathrm{e}$ and 62 e clusters with formation of M-S and M-M bonds on addition of two $11 \mathrm{e}$ or $12 \mathrm{e}$ $\mathrm{M}^{\prime} \mathrm{L}_{\mathbf{n}}$ fragments respectively.

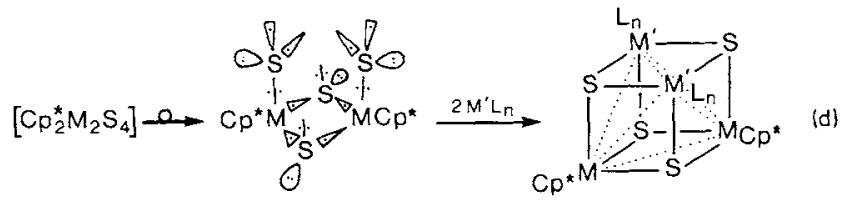

Typical examples of directed syntheses of homo- and bimetallic clusters are listed in Table 1. $\mathrm{Cp}^{(*)} \mathrm{M}(\mathrm{M}=\mathrm{Cr}$, $\mathrm{Mo}),{ }^{[94]} \mathrm{Fe}(\mathrm{NO})^{[95]}$ and $\mathrm{Co}(\mathrm{CO})^{[96]}$ can serve as $11 \mathrm{e}$ fragments, i.e. also complex-fragments with easily substituted ligands, so that ligand substitutions in the clusters are possible without destroying the cluster skeleton. Thus, e.g., the $\mathrm{CO}$ ligands in $\left[\mathrm{Cp}_{2}^{*} \mathrm{Cr}_{2} \mathrm{Co}_{2}(\mathrm{CO})_{2} \mathrm{~S}_{4}\right]$ can be successively substituted by $\mathrm{P}(\mathrm{OMe})_{3}$ without fragmentation of the cluster framework. ${ }^{[97]}$

All the $60 \mathrm{e} \mathrm{M}_{2} \mathrm{M}_{2}^{\prime} \mathrm{S}_{4}$ clusters possess a distorted cubic ('pseudocubane') structure with incorporated $\mathrm{M}_{4}$ and $\mathrm{S}_{4}$ tetrahedra-they have six $\mathrm{M}-\mathrm{M}$ bonds for electronic reasons..$^{[29,97,98]}$ The attainment of the same cubic structure is also the motive behind the formation of the $56 \mathrm{e}, 58 \mathrm{e}$, and 60 e clusters, even if the presence of the vanadium atoms provokes magnetic anomalies. All Vanadium clusters are accessible from the $36 \mathrm{e}$ building block 3 (Table 1).

Addition of the $12 \mathrm{e}$ fragments $\mathrm{Mo}(\mathrm{CO})_{3}, \mathrm{Fe}(\mathrm{CO})_{2}$ or $\mathrm{Cu}$ $\mathrm{Cl}$ to 22 a leads ultimately to stable $62 \mathrm{e}$ heterocubanes (Table 1 ) containing only five $\mathrm{M}-\mathrm{M}$ bonds. ${ }^{[91,1001}$ Clusters with both oxo- and thio-ligands can be prepared in the same way. Thus, for example, the cluster $\left[\mathrm{Cp}_{2}^{*} \mathrm{Mo}_{2} \mathrm{Cr}_{2}(\mathrm{CO})_{6} \mathrm{O}_{2} \mathrm{~S}_{2}\right]$ can be isolated from the reaction of $\left[\mathrm{Cp}_{2}^{*} \mathrm{Mo}_{2} \mathrm{O}_{2} \mathrm{~S}_{2}\right]$ with $\left[\mathrm{Cr}(\mathrm{CO})_{3}(\mathrm{MeCN})_{3}\right]^{[52 a]}$

The results obtained from the analogous reactions with 16 are less consistent. The reaction with $\mathrm{Ni}(\mathrm{CO})_{4}$ is the only reaction which gives a product, namely $\left[\mathrm{Cp}_{2} \mathrm{Mo}_{2} \mathrm{Ni}_{2}(\mathrm{CO})_{2} \mathrm{~S}_{4}\right]$, with the expected $62 \mathrm{e}$ pseudocubane type structure. ${ }^{[101]} \mathrm{In}$ contrast, $\mathrm{CO}_{2}(\mathrm{CO})_{8}$ reacts with 16 not only with elimination of $\mathrm{CO}$ but also of $\mathrm{H}_{2} \mathrm{~S}$, thus yielding 67. Two edge-sharing $\mathrm{Mo}_{2} \mathrm{CoS}$ tetrahedra spanned by a $\mu_{4}-\mathrm{S}$ ligand are characteristic of this cluster. ${ }^{[101]}$ The reaction of 16 with $\mathrm{Fe}(\mathrm{CO})_{5}{ }^{[102]}$ or $\mathrm{Fe}_{2}(\mathrm{CO})_{9}{ }^{[101]}$ also yields a completely different sort of product, the 66 e cluster 70. This has only $3 \mathrm{M}-\mathrm{M}$ bonds, all metal atoms lying in one plane. Whether 70 can be converted into a cluster of the type 69 , has evidently not been investigated.

It is not the SH ligands that are responsible for the differing behavior of 16 , but rather the $\mathrm{Cp}^{(*)}$ ligands: the permethylated derivative 65 reacts with $\mathrm{Co}_{2}(\mathrm{CO})_{8}$ to give $\left[\mathrm{Cp}_{2}^{*} \mathrm{Mo}_{2} \mathrm{Co}_{2}(\mathrm{CO})_{2} \mathrm{~S}_{4}\right]$, which has a 'normal' $60 \mathrm{e} \mathrm{M}_{4} \mathrm{~S}_{4}$ core. ${ }^{[103]}$

\section{Conclusion and Perspectives}

This review should hopefully have illustrated the appeal of the extremely variable structural chemistry of sulfur ligands from the organometallic point of view with particular reference to the dimeric cyclopentadienyl-transition metal complexes. The reactivity potential of these complexes has also been outlined. The unpredictable coexistence of mono-, diand polysulfur ligands as well as the abilities to undergo ligand transformations and to be effective $\pi$-donor ligands, guarantee future developments in the structural chemistry and reactivity of these complexes. Although it is relatively difficult to present rigid principles, it was possible to show by

Table 1. Overview of the syntheses of homo- and heteronuclear clusters with the $\mathrm{M}_{2} \mathrm{M}_{2}^{\prime}$ core from $\left[\mathrm{Cp}_{2}^{(*)} \mathrm{M}_{2} \mathrm{~S}_{\mathrm{r}}\right]$ complexes $(\mathrm{n}=4,5)$.

\begin{tabular}{|c|c|c|c|c|c|}
\hline Substrate & Reactant & Conditions & Chuster & $\mathrm{n}[\mathrm{a}]$ & Ref. \\
\hline$\left[\mathrm{Cp}_{2}^{\prime} \mathrm{V}_{2} \mathrm{~S}_{4}\right] 3$ & $\begin{array}{l}{\left[\mathrm{Cp}_{2}^{\prime} \mathrm{V}_{2} \mathrm{~S}_{4}\right]} \\
\mathrm{Hg}\left[\mathrm{Fe}(\mathrm{CO})_{3}(\mathrm{NO})\right]_{2} \\
{\left[\mathrm{Co}(\mathrm{CO})_{3}(\mathrm{NO})\right]}\end{array}$ & $\begin{array}{l}\mathrm{PBu}_{3} ; 20^{\circ} \mathrm{C} \\
\text { toluene; } 115^{\circ} \mathrm{C} \\
\mathrm{CH}_{2} \mathrm{Cl}_{2} ; 20^{\circ} \mathrm{C}\end{array}$ & $\begin{array}{l}{\left[\mathrm{Cp}_{4}^{\prime} \mathrm{V}_{4} \mathrm{~S}_{4}\right]} \\
{\left[\mathrm{Cp}_{2}^{\prime} \mathrm{V}_{2} \mathrm{Fe}_{2}(\mathrm{NO})_{2} \mathrm{~S}_{4}\right]} \\
{\left[\mathrm{Cp}_{2}^{\prime} \mathrm{V}_{2} \mathrm{Co}_{2}(\mathrm{NO})_{2} \mathrm{~S}_{4}\right]}\end{array}$ & $\begin{array}{l}56 \\
58 \\
60\end{array}$ & $\begin{array}{l}{[99]} \\
{[76 \mathrm{~b}]} \\
{[76 \mathrm{~b}]}\end{array}$ \\
\hline$\left[\mathrm{Cp}_{2}^{*} \mathrm{Cr}_{2} \mathrm{~S}_{5}\right] 8$ & $\begin{array}{l}{\left[\mathrm{Cp}_{2} \mathrm{Cr}_{2}(\mathrm{CO})_{4}\right]} \\
{\left[\mathrm{Cp}_{2}^{*} \mathrm{Cr}_{2} \mathrm{~S}_{5}\right]} \\
{\left[\mathrm{Fe}(\mathrm{CO})_{3}(\mathrm{NO})\right]\left[\left(\mathrm{Ph}_{3} \mathrm{P}\right)_{2} \mathrm{~N}\right]} \\
\mathrm{Co}_{2}(\mathrm{CO})_{8}\end{array}$ & $\begin{array}{l}\text { THF; } h v \\
\mathrm{H}_{2} ; 150 \text { bar, } 80^{\circ} \mathrm{C} \\
\text { THF; } h v \\
\text { toluene; } 20^{\circ} \mathrm{C}\end{array}$ & $\begin{array}{l}{\left[\mathrm{Cp}_{2}^{*} \mathrm{Cp}_{2} \mathrm{Cr}_{4} \mathrm{~S}_{4}\right]} \\
{\left[\mathrm{Cp}_{4}^{*} \mathrm{Cr}_{4} \mathrm{~S}_{4}\right]} \\
{\left[\mathrm{Cp}_{2}^{*} \mathrm{Cr}_{2} \mathrm{Fe}_{2}(\mathrm{NO})_{2} \mathrm{~S}_{4}\right]} \\
{\left[\mathrm{Cp}_{2}^{*} \mathrm{Cr}_{2} \mathrm{Co}_{2}(\mathrm{CO})_{2} \mathrm{~S}_{4}\right]}\end{array}$ & $\begin{array}{l}60 \\
60 \\
60 \\
60\end{array}$ & $\begin{array}{l}{[94]} \\
{[23]} \\
{[95]} \\
{[96]}\end{array}$ \\
\hline$\left[\mathrm{Cp}_{2}^{*} \mathrm{Mo}_{2} \mathrm{~S}_{4}\right] 22 \mathrm{a}$ & $\begin{array}{l}{\left[\mathrm{Cp}_{2} \mathrm{Cr}_{2}(\mathrm{CO})_{4}\right]} \\
{\left[\mathrm{Cp}_{2} \mathrm{Mo}_{2}(\mathrm{CO})_{4}\right]} \\
{\left[\mathrm{Fe}(\mathrm{CO})_{3}(\mathrm{NO})\right]\left[\left(\mathrm{Ph}_{3} \mathrm{P}\right)_{2} \mathrm{~N}\right]} \\
\mathrm{Co}(\mathrm{CO})_{8} \\
\mathrm{Mo}(\mathrm{CO})_{6} \\
\mathrm{Fe}(\mathrm{CO})_{5} \\
\mathrm{CuCl}\end{array}$ & $\begin{array}{l}\text { THF; } h v \\
\text { toluene; } 115^{\circ} \mathrm{C} \\
\text { THF; } h v \\
\text { toluene; } 20^{\circ} \mathrm{C} \\
\text { toluene; } 115^{\circ} \mathrm{C} \\
\text { THF; } 25^{\circ} \mathrm{C} \\
\mathrm{CH}_{2} \mathrm{Cl}_{2} ; 20^{\circ} \mathrm{C}\end{array}$ & $\begin{array}{l}{\left[\mathrm{Cp}_{2}^{*} \mathrm{Mo}_{2} \mathrm{Cp}_{2} \mathrm{Cr}_{2} \mathrm{~S}_{4}\right]} \\
{\left[\mathrm{Cp}_{2}^{*} \mathrm{Cp}_{2} \mathrm{Mo}_{4} \mathrm{~S}_{4}\right]} \\
{\left[\mathrm{Cp}_{2}^{*} \mathrm{Mo}_{2} \mathrm{Fe}_{2}(\mathrm{NO})_{2} \mathrm{~S}_{4}\right]} \\
{\left[\mathrm{Cp}_{2}^{*} \mathrm{Mo}_{2} \mathrm{Co}_{2}(\mathrm{CO})_{2} \mathrm{~S}_{4}\right]} \\
{\left[\mathrm{Cp}_{2}^{*} \mathrm{Mo}_{4}(\mathrm{CO})_{6} \mathrm{~S}_{4}\right]} \\
{\left[\mathrm{Cp}_{2}^{*} \mathrm{Mo}_{2} \mathrm{Fe}_{2}(\mathrm{CO})_{4} \mathrm{~S}_{4}\right] 69} \\
{\left[\mathrm{Cp}_{2}^{*} \mathrm{Mo}_{2} \mathrm{Cu}_{2}(\mathrm{Cl})_{2} \mathrm{~S}_{4}\right]}\end{array}$ & $\begin{array}{l}60 \\
60 \\
60 \\
60 \\
62 \\
62 \\
62\end{array}$ & $\begin{array}{l}{[94]} \\
{[94]} \\
{[95]} \\
{[96]} \\
{[91]} \\
{[91]} \\
{[100]}\end{array}$ \\
\hline$\left[\mathrm{Cp}_{2} \mathrm{Mo}_{2} \mathrm{~S}_{2}(\mathrm{SH})_{2}\right] 16$ & $\mathrm{Ni}(\mathrm{CO})_{4}$ & $\mathrm{THF} ; 25^{\circ} \mathrm{C}$ & {$\left[\mathrm{Cp}_{2} \mathrm{Mo}_{2} \mathrm{Ni}_{2}(\mathrm{CO})_{2} \mathrm{~S}_{4}\right]$} & 62 & [101] \\
\hline
\end{tabular}

[a] Number of valence electrons in the cluster. 
means of thermal, photochemical or electrochemical investigations that some relationships exist within groups of certain complex types. Above all, it would appear that electrochemistry will play an important role in the future, for such investigations should not only make up for the general lack of redox-active inorganic metal-sulfur complexes ${ }^{[104]}$ but also open up the possibility of investigating new reaction types. ${ }^{[78,80,83]}$

The search for mixed chalcogen-pnicogen ligands could be a particularly fruitful field in which to extend our present knowledge of complexes of $\mathrm{Cp}$ with $\mathrm{O}$, Se and Te ligands. This is immediately apparent on comparing the structural relationships between, e.g., 48 and $\left[\mathrm{Cp}_{2}^{*} \mathrm{Cr}_{2} \mathrm{P}_{5}\right]^{[105]}$ or $\left[\mathrm{Cp}_{2} \mathrm{Mo}_{2} \mathrm{As}_{5}\right]^{[1061}$ despite their differing bonding systems. In this connection, the first success in this search may have been the formal substitution of one and of three $\mathrm{P}$ atoms of the cyclo- $\mathrm{P}_{5}$ ligand of $\left[\mathrm{Cp}_{2}^{*} \mathrm{Mo}_{2} \mathrm{P}_{5}\right]$ by sulfur atoms. ${ }^{[107]}$

Because of the nucleophilicity of their monosulfido ligands the sulfur-rich complexes of the vanadium and chromium triads exhibit model character for the study of heterogeneous metal sulfide surfaces in commercially important hydrodesulfurization catalyses. ${ }^{[108]}$ However, with regard to the excellent HDS properties of $\mathrm{RuS}_{2}$ and $\mathrm{Rh}_{2} \mathrm{~S}_{3}{ }^{[109]}$ the suitability of sulfur-rich Ru- and Rh-complexes described in this contribution would be well worth investigation.

Since the active centers of commercial HDS catalysts also consist of $\mathrm{MoM}$ 'S phases $\left(\mathrm{M}^{\prime}=\mathrm{Fe}, \mathrm{Co}, \mathrm{Ni}\right)^{\left[1{ }^{10]}\right.}$ the preparation of heteronuclear clusters with an $\mathrm{M}_{4} \mathrm{~S}_{4}$ core [Eq. (d)] using the synthetic concepts developed for the complexes $\left[\mathrm{Cp}_{2}^{(*)} \mathrm{M}_{2} \mathrm{~S}_{4}\right]$ could be of some importance. Actually, novel sulfur-resistant $\mathrm{CO}$ hydrogenation and HDS catalysts can be prepared $^{[111]}$ from 67 and 70 by coating them on oxidic supports which are then calcinated in an $\mathrm{H}_{2}$ atmosphere. It should also be pointed out that striving for a high $\mathrm{Fe}: \mathrm{M}$ ratio (particularly when $\mathrm{M}=\mathrm{Mo}$ ) or replacing the $\mathrm{Cp}$ ligands by, e.g., dithiocarbamato ligands could lead to the creation of clusters of physiological importance..$\left.^{1} 112\right]$

\section{I should once again thank my own co-workers cited in the reference section for their engaged contribution. Since conven- tional spectroscopic data on the compounds mentioned do not lead to a definite structural conclusion because of the very simple ligand situation, $X$-ray structural analysis has been of considerable importance. I would therefore particularly like to thank Prof. Dr. M. L. Ziegler (Universität Heidelberg) and his co-workers for their continued support since the very early stages of this work, and Dr. U. Klement (Universität Regens- burg). I am particularly indebted to Prof. Dr. H. Brunner for generous material support and for the goodwill this work re- quired and to Frau Karin Kilgert for the preparation of the manuscript.}

Received: April 13,1989 [A 743 IE] German version: Angew. Chem. 101 (1989) 1645

[1] An insight into the nature of the structural problems of the Fe-Mo cofactor of nitrogenase can be found, e.g., in the following works: S. D. Conradson, B. K. Burgess, W. E. Newton, L. E. Mortenson, K. O. Hodgson, J. Am. Chem. Soc. 109 (1987) 7507; B. Hedman, P. Franck, S. F. Gheller, L. Roe, W. E. Newton, K. O. Hodgson, ibid. 110 (1988) 3798. The synthetic efforts to solve this problem are summarized in R. H. Holm. E. D. Simhon in T. G. Spiro (Ed.): Molybdenum Enzymes, Wiley, New York 1985. p. $1 \mathrm{ff}$.
[2] F. E. Massoth, Adv. Catal. 27 (1978) 265; W. Eltzner, M. Breysse, M. Lacroix, C. Lequlerq, M. Vrinat, A. Müller, E. Diemann. Polyhedron 7 (1988) 2405.

[3] H. Vahrenkamp, Angew. Chem. 87 (1975) 363; Angew. Chem. Int. Ed. Engl. 14 (1975) 322.

[4] A. Müller, W. Jaegermann, J. H. Enemark, Coord. Chem. Rev. 46 (1982) 245.

[5] a) M. Draganjac, T. B. Rauchfuss, Angew. Chem. 97 (1985) 745; Angew Chem. Int. Ed. Engl. 24 (1985) 742; b) A. Müller, E. Diemann, Adv. Inorg. Chem. 31 (1987) 89.

[6] J. Wachter, J. Coord. Chem. 15 (1987) 219.

[7] a) F. Bottomley, J. Darkwa, L. Sutin, P. S. White, Organometallics 5 (1986) 2165; F. Bottomley, L. Sutin, Adv. Organomet. Chem. 28 (1988) 339; b) W. A. Herrmann, E. Herdtweck, M. Flöel, J. Kulpe. U. Küsthardt, J. Okuda, Polvhedron 6 (1987) 1165; c) W. A. Herrmann, Angew Chem. 100 (1988) 1269; Angew. Chem. Int. Ed. Engl. 27 (1988) 1297.

[8] D. M. Giolando, T. B. Rauchfuss, A. L. Rheingold, S. R. Wilson, Organometallics 6 (1987) 667.

[9] D. M. Giolando, M. Papavassiliou, J. Pickardt, T. B. Rauchfuss, R. Steudel, Inorg. Chem. 27 (1988) 2596.

[10] A. Shaver, J. M. McCall, Organometallics 3 (1984) 1823; F. Bottomley, G. O. Egharevba, P. S. White, J. Am. Chem. Soc. 107 (1985) 4353; F Bottomley, D.F. Drummond, G. O. Egharevba, P.S. White, Organometallics 5 (1986) 1620.

[11] F. Bottomley, T.-T. Chin, G. O. Egharevba, L. M. Kane, D. A. Pataki, P. S. White, Organometalics 7 (1988) 1214.

[12] G. Erker, T. Mühlenbernd, R. Benn, A. Rufinska, G. Tainturier, B. Gautheron, Organometallics 5 (1986) 1023; G. Erker, T. Mühlenbernd, R. Nolte, J. L. Petersen, G. Tainturier, B. Gautheron, J. Organomet. Chem. 314 (1986) C21.

[13] N. Albrecht, E. Weiss, J. Organomet. Chem. 355 (1988) 89.

[14] K. G. Muller, J. L. Petersen, L. F. Dahl, J. Organomet. Chem. 111 (1976) 91.

[15] C. M. Bolinger, T. B. Rauchfuss, A. L. Rheingold, Organometallics 1 (1982) 1551; A. L. Rheingold, C. M. Bolinger, T. B. Rauchfuss, Acta Crysiallogr. Sect. C 42 (1986) 1878.

[16] D. Fenske, J. Ohmer, J. Hachyenei, K. Merzweiler, Angew. Chem. to0 (1988) 1300; Angew. Chem. Int. Ed. Engl. 27 (1988) 1277.

[17] M. Herberhold, M. Kuhnlein. New. J. Chem. 12 (1988) 357.

[18] C. M. Bolinger, T. B. Rauchfuss, A. L. Rheingold, J. Am. Chem. Soc. 105 (1983) 6321.

[19] Y. V. Skripkin, I. L. Eremenko, A. A. Pasynskii, Y. T. Struchkov, V. E. Shklover, J. Organomet. Chem. 267 (1984) 285

[20] H. Brunner, U. Klement, J. Wachter, M. Tsunoda, J.C. Leblanc, C. Moise, Inorg. Chem in press; H. Brunner, W. Meier, J. Wachter. B. Nuber, M. L. Ziegier, J. Organomet. Chem. in press.

[21] W. A. Herrmann, H. Biersack, M. L. Ziegler. B. Balbach. J. Organomet. Chem. 206 (1981) C 33.

[22] H. Brunner, J. Wachter, E. Guggolz, M. L. Ziegler, J. Am. Chem. Soc. 104 (1982) 1765.

[23] H. Brunner, H. Kauermann, W. Meier, J. Wachter, J. Organomet. Chem $263(1984) 183$

[24] H. Brunner, J. Pfauntsch, J. Wachter, B. Nuber, M. L. Ziegler, J. Organomet. Chem. 359 (1989) 179.

[25] 1.-P. Lorenz, J. Messelhäuser, W. Hiller, K. Haag, Angen: Chem. 97 (1985) 234; Angew. Chem. Int. Ed. Engl. 24 (1985) 228.

[26] L. Y. Goh, T. W. Hambley, G. B. Robertson, Organometallics 6 (1987) 1051

[27] Complexes with the M-E-M skeleton $(\mathrm{E}=\mathrm{S}, \mathrm{Se})$ are comprehensively referenced in W. A. Herrmann, Angew. Chem. 98 (1986) 57; Angew. Chem. Int. Ed. Engl. 25 (1986) 56.

[28] L. Y. Goh. T. C. W. Mak, J. Chem. Soc. Chem. Commun. 1986, 1474

[29] A. A. Pasynskii, I. L. Eremenko, Sov. Sci. Rev. Sect. B 10 (1987) 443

[30] R. B. King, M. Z. Iqbal, A. D. King, Jr., J. Organomet. Chem. 771 (1979) 53.

[31] M. D. Curtis, W. M. Butler, J. Chem. Soc. Chem. Commun. 1980.998.

[32] R. A. Schunn, C. J. Fritchie, Jr., C. T. Prewitt, Inorg. Chem. 5 (1966) 892.

[33] M. Rakowski DuBois, D. L. DuBois, M. C. Van Derveer, R. C. Haltiwanger, Inorg. Chem. 20 (1981) 3064.

[34] M. Rakowski DuBois, M. C. Van Derveer, D. L. DuBois, R. C. Haltiwanger, W. K. Miller, J. Am. Chem. Soc. $102(1980) 7456$.

[35] M. D. Curtis, P. D. Williams, Inorg. Chem. 22 (1983) 2661

[36] K. Endrich, E. Guggolz, O. Serhadli, M. L. Ziegler, R. R. Korswagen, J. Organomet. Chem. 349 (1988) 323.

[37] H. Brunner, W. Meier, J. Wachter, E. Guggolz. T. Zahn, M. L. Ziegler, Organometallics 1 (1982) 1107.

[38] H. Brunner, J. Wachter, H, Wintergerst, J. Organomet. Chem. 235 (1982) 77.

[39] W. Tremel, R. Hoffmann, E. D. Jemmis, Inorg. Chem. 28 (1989) 1213.

[40] A. E. Bruce, D. R. Tyler, Inorg. Chem. 23 (1984) 3433.

141] D. L. DuBois, W. K. Miller. M. Rakowski DuBois, J. Am. Chem. Soc. 103 (1981) 3429; J. M. Newsam. T. R. Halbert. Inorg. Chem. 24 (1985) 491.

[42] W. Beck, W. Danzer, G. Thiel, Angew. Chem. 85 (1973) 625; Angew Chem. Int. Ed. Engl. 12 (1973) 582; W. Danzer, W. P. Fehlhammer, A. T. 
Liu, G. Thiel, W. Beck, Chem. Ber. 115 (1982) 1682; M. Rakowski DuBois, R. C. Haltiwanger, D. J. Miller, G. Glatzmeier, J. Am. Chem. Soc. 101 (1979) 5245.

[43] E. O. Fischer, K. Ulm, H. P. Fritz, Chem. Ber. 93 (1960) 2167; F. Bottomley, D. E. Paez, P. S. White, J. Am. Chem. Soc. 104 (1982) 5651.

[44] M. Cousins, M. L. H. Green, J. Chem. Soc. 1964, 1567; C. Couldwell, K. Prout, Acta Crystallogr. Sect. B34 (1978) 933.

[45] M. Herberhold, W. Kremnitz, U. Thewalt, A. Razawi, H. Schöllhorn, Angew. Chem. 97 (1985) 603; Angew. Chem. Int. Ed. Engl. 24 (1985) 601.

[46] K. Isobe, S. Kimura, Y. Nakamura, J. Organomet. Chem. 331 (1987) 221.

[47] J. W. Faller, Y. Ma, J. Organomet. Chem. 340 (1988) 59; P. Gomez-Sal, E. de Jesus, A. Vazquez de Miguel, S. Martinez-Carrera, S. Garcia-Blanco, ibid. 353 (1988) 191.

[48] H. Arzoumanian, A. Baldy, M. Pierrot, J.-F. Petrignani, J. Organomet. Chem. 294 (1985) 327.

[49] W. A. Herrmänn, J. Organomet. Chem. 300 (1986) 111

[50] H. G. Alt, H. I. Hayen, R. D. Rogers, J. Chem. Soc. Chem. Commun. 1987, 1795.

151] P. M. Treichel, G. R. Wilkes, Inorg. Chem. 5 (1966) 1182; D. L. Stevenson, L. F. Dahl, J. Am. Chem. Soc. 89 (1967) 3721.

[52] a) H. Brunner, H. Kauermann, J. Pfauntsch, J. Wachter, J. H. Enemark, C. G. Young, J. Organomet. Chem. 331 (1987) 45; b) L. D. Tanner, R. C. Haltiwanger, M. Rakowski DuBois, Inorg. Chem. 27 (1988) 1741.

[53] C. G. Young, M. Minelli, J. H. Enemark, G. Miessler, N. Janietz, H. Kauermann, J. Wachter, Polyhedron 5 (1986) 407; C. J. Casewitt, M. Rakowski DuBois, R. A. Grieves, J. Mason, Inorg. Chem. 26 (1987) 1889.

[54] M. Herberhold, B. Schmidkonz, J. Organomet. Chem. 308 (1986) 35.

[55] H. Brunner, U. Klement, J. Pfauntsch, J. Wachter, Angew. Chem. 99 (1987) 268; Angew. Chem. Int. Ed. Engl. 26 (1987) 230.

[56] M. Herberhold, B. Schmidkonz, J. Organomet. Chem. 358 (1988) 301.

[57] M. Herberhold, D. Reiner, K. Ackermann, U. Thewalt, T. Debaerdemaeker, Z. Naturforsch. B35 (1980) 1281.

[58] W. A. Herrmann, M. Flöel, J. Kulpe, J. K. Felixberger, E. Herdtweck, J. Organomet. Chem. 355 (1988) 297.

[59] C. H. Wei, G. R. Wilkes, P. M. Treichel, L. F. Dahl, Inorg. Chem. 5 (1966) 900.

[60] H. Brunner, N. Janietz, W. Meier, G. Sergeson, J. Wachter, T. Zahn, M. L. Ziegler, Angew. Chem. 97 (1985) 1056; Angew. Chem. Int. Ed. Engl. 24 (1985) 1060 .

[61] a) H. Chanaud, A. M. Ducourant, G. Giannotti, J. Organomet. Chem. 190 (1980) 201 ; b) R. Weberg, R. C. Haltiwanger, M. Rakowski DuBois, Organometallics 4 (1985) 1315.

[62] P. J. Vergamini, R. Ryan, G. Kubas, J. Am. Chem. Soc. 98 (1976) 1980 ; P. J. Vergamini, G. J. Kubas, Prog. Inorg. Chem. 21 (1976) 261.

[63] M. A. El-Hinnawi, A. A. Aruffo, B. D. Santarsiero, R. McAlister, V. Schomaker, Inorg. Chem. 22 (1983) 1585.

[64] N. Janietz, Dissertation, Universität Regensburg 1989.

[65] H. B. Abrahamson, M. C. Palazzotto, C. L. Reichel, M. S. Wrighton, J. Am. Chem. Soc. 101 (1979) 4123.

[66] Concepts of the radical degradation of the $S_{8}$ molecule that are relevant to the reaction with $\left[\mathrm{Cp}^{*} \mathrm{Ru}(\mathrm{CO})_{2}\right]_{2}$ can be found, e.g., in C. Floriani, $\mathrm{M}$. Fiallo, A. Chiesi-Villa, C. Guastini, J. Chem. Soc. Dallon Trans. 1987 1367.

[67] H. Brunner, N. Janietz, J. Wachter, B. Nuber, M. L. Ziegler, $J$. Organomet. Chem. 356 (1988) 85.

[68] J. Amarasekera, T. B. Rauchfuss, A. L. Rheingold, Inorg. Chem. 26 (1987) 2017.

[69] T. B. Rauchfuss, D. P. S. Rodgers, S. R. Wilson, J. Am. Chem. Soc, 108 (1986) 3114 ; J. Amarasekera, T. B. Rauchfuss, S. R. Wilson, J. Chem. Soc. Chem. Commun, 1989, 14.

[70] W. A. Herrmann, J. Rohrmann, E. Herdtweck, C. Hecht, M. L. Ziegler, O. Serhadli, J. Organomet. Chem. 314 (1986) 295.

[71] R. M. Roder, Ph. D. Thesis, University of Wisconsin-Madison 1973; H. Ogino, H. Tobita, K. Yanagisawa, M. Shimoi, C. Kabuto, J. Am. Chem Soc. 109 (1987) 5847

[72] H. Brunner, N. Janietz, W. Meier, B. Nuber, J. Wachter, M. L. Ziegler, Angew. Chem. 100 (1988) 717; Angew. Chem. Int. Ed. Engl. 27 (1988) 708.

[73] C. Bianchini, A. Meli, Inorg. Chem. 26 (1987) 1346.

[74] a) H. Brunner, W. Meier, B. Nuber, J. Wachter, M. L. Ziegler, Angew. Chem. 98 (1986) 907; Angew. Chem. Int. Ed. Engl. 25 (1986) 908; b) H. Brunner, N. Janietz, W. Meier, J. Wachter, E. Herdtweck, W. A. Herrmann, O. Serhadli, M. L. Ziegler, J. Organomet. Chem. 347 (1988) 237; H. Brunner, N. Janietz, J. Wachter, B. Nuber, M. L. Ziegler, ibid. 367 (1989) 197

[75] W. Rittner, A. Müller, A. Neumann, W. Bäther, R. C. Sharma, Angew Chem. 91 (1979) 565; Angew. Chem. Int. Ed. Engl. 18 (1979) 530; S.
Sarkar, M. A. Ansari, J. Chem. Soc. Chem. Commun. 1986, 342; M. A. Ansari, J. Chandrasekeran, S. Sarkar, Polyhedron 7 (1987) 471.

[76] a) C. M. Bolinger, T. B. Rauchfuss, S. R. Wilson, J. Am. Chem. Soc. 104 (1982) 7313 ; b) T. B. Rauchfuss, T. D. Weatherill, S. R. Wilson, J.P. Zebrowski, ibid. 105 (1983) 6508.

[77] C. M. Bolinger, T. B. Rauchfuss, S. R. Wilson, J. Am. Chem. Soc. 100 (1984) 7800 .

[78] H. Brunner, A. Merz, J. Pfauntsch, O. Serhadli, J. Wachter, M. L. Ziegler, Inorg. Chem. 27 (1988) 2055; H. Ogino, H. Tobita, S. Inomata, M. Shimoi, J. Chem. Soc. Chem. Commun. 1988, 586.

[79] H. Brunner, W. Meier, P. Weber, M. L. Ziegler, J. H. Enemark, C. G. Young, J. Organomet. Chem. 309 (1986) 313

[80] a) M. McKenna, L. L. Wright, D. J. Miller, L. Tanner, R. C. Haltiwanger, M. Rakowski DuBois, J. Am. Chem. Soc. 105 (1983) 5329; b) C. J. Casewitt, R. C. Haltiwanger, J. Noordik, M. Rakowski DuBois. Organometallics 4 (1985) 119.

[81] J. C. V. Laurie, L. Duncan, R. C. Haltiwanger, R. T. Weberg, M. Rakowski DuBois, J. Am. Chem. Soc. 108 (1986) 6234; R. T. Weberg, R. C. Haltiwanger, J. C. V. Laurie, M. Rakowski DuBois, ibid. 108 (1986) 6242; D. E. Coons, R. C. Haltiwanger, M. Rakowski DuBois, Organometallics 6 (1987) 2417

[82] D. E. Coons, J. C. V. Laurie, R. C. Haltiwanger, M. Rakowski DuBois, J. Am. Chem. Soc. 109 (1987) 283

[83] O. A. Rajan, M. McKenna, J. Noordik, R. C. Haltiwanger, M. Rakowski DuBois, Organometallies 3 (1984) 831 ; L. D. Tanner, R. C. Haltiwanger, J. Noordik, M. Rakowski DuBois, Inorg. Chem. 27 (1988) 1736.

[84] E. H. M. Badger, R. H. Friggith, W. S. B. Newling, Proc. R. Soc. London Ser. A 197 (1949) 184.

[85] F. E. Massoth, C. L. Kibby, J. Catal. 47 (1977) 300; F. E. Massoth, ibid. 47 (1977) 316; H. C. Kwart, G. C. A. Schuit, B. C. Gates, ihid. 61 (1980) 128.

[86] C. J. Casewitt, D. E. Coons, L. L. Wright, W. K. Miller, M. Rakowski DuBois, Organometallics 5 (1986) 951.

[87] G. J. Kubas, R. R. Ryan, J. Am. Chem. Soc. 107 (1985) 6138.

[88] J. Pfauntsch, Dissertation, Universität Regensburg 1988.

[89] H. Brunner, N. Janietz, J. Wachter, H.-P. Neumann, B. Nuber, M. L. Ziegler, unpublished.

[90] G. J. Kubas, R. R. Ryan, K. A. Kubat-Martin, E. Larson, J. Am. Chem. Soc. $111(1989) 7823$.

[91] H. Brunner, N. Janietz, J. Wachter, T. Zahn, M. L. Ziegler, Angew. Chem. 97 (1985) 122; Angew. Chem. Int. Ed. Engl. 24 (1985) 133.

[92] C. M. Bolinger, T. D. Weatherill, T. B. Rauchfuss, A. L. Rheingold, C. S. Day, S. R. Wilson, Inorg. Chem. 25 (1986) 634

[93] B. K. Teo, G. Longoni, F. R. K. Chung, Inorg. Chem. 23 (1984) 1257.

[94] H. Brunner, H. Kauermann, J. Wachter, J. Organomet. Chem. 265 (1984) 189

[95] H. Brunner, H. Kauermann, J. Wachter, Angew. Chem. 95 (1983) 567; Angew. Chem. Int. Ed. Engl. 22 (1983) 549.

[96] H. Brunner, J. Wachter, J. Organomet. Chem. 240 (1982) C41.

[97] H. Brunner, W. Meier, J. Wachter, H. Pfisterer, M. L. Ziegler, Z. Naturforsch. B40 (1985) 923.

[98] J. A. Bandy, C. E. Davies, C. Green, M. L. H. Green, K. Prout, D. P. S. Rodgers, J. Chem. Soc. Chem. Commun. 1983, 1395.

[99] J. Darkwa, J. R. Lockemeyer, P. D. W. Boyd, T. B. Rauchfuss, A. L. Rheingold, J. Am. Chem. Soc. 110 (1988) 141

[100] H. Brunner, R. Grassl, J. Wachter, B. Nuber, M. L. Ziegler, unpublished.

[101] M. D. Curtis, P. D. Williams, W. M. Butler, Inorg. Chem. 27 (1988) 2853.

[102] B. A. Cowans, R. C. Haltiwanger, M. Rakowski DuBois, Organometallics $6(1987) 995$

[103] N. Janietz, J. Wachter, unpublished results.

[104] See for example G. J. Kubas, P. J. Vergamini, Inorg. Chem. 20 (1981) 2667; F. Cecconi, C. A. Ghilardi, S. Midollini, A. Orlandini, P. Zanello, J. Chem. Soc. Dalton Trans. 1987, 831.

[105] O. J. Scherer, J. Schwalb, G. Wolmershäuser, W. Kaim, R. Gross, Angew. Chem. 98 (1986) 349; Angew. Chem. Ini. Ed. Engl. 25 (1986) 363.

[106] A. L. Rheingold, M. J. Foley, P. J. Sullivan, J. Am. Chem. Soc. 104 (1982) 4727.

[107] H. Brunner, U. Klement, W. Meier, J. Wachter, O. Serhadli, M. L. Ziegler, J. Organomet. Chem. 335 (1987) 339.

[108] For a summary of the catalytic uses of transition-metal complexes with sulfido ligands, see: M. Rakowski DuBois, Chem. Rev. 89 (1989) 1.

[109] T. A. Pecoraro, R. R. Chianelli, J. Catal. 67 (1981) 430.

[110] N.-Y. Topsøe, H. Topsøe, J. Catal. 84 (1983) 386.

[111] M. D. Curtis, J. E. Penner-Hahn, J. Schwank, O. Baralt, D. J. McCabe, L. Thompson, G. Waldo, Polyhedron 7 (1988) 2411.

[112] T. R. Halbert, S. A. Cohen, E. I. Stiefel, Organometallics 4 (1985) 1689. 